DOI:10.22337/2587-9618-2020-16-1-106-129

\title{
A.A. ILYUSHIN'S FINAL RELATION, ALTERNATIVE EQUIVALENT RELATIONS AND VERSIONS OF ITS APPROXIMATION IN PROBLEMS OF PLASTIC DEFORMATION OF PLATES AND SHELLS PART 1: A.A. ILYUSHIN'S FINAL RELATION
}

\author{
Aleksandr V. Starov, Sergei .JU. Kalashnikov \\ Volgograd state technical university, Volgograd, RUSSIA
}

\begin{abstract}
The finite relationship between the forces and moments of plates and shells in the parametric form of the theory of small elastoplastic deformations is investigated of A.A. Ilyushin, to determine the load-bearing capacity of structures from a material without hardening. A geometric image of the exact yield surface in the space of generalized stresses is obtained. In the first part of the article the conclusion of the final relation is given. In the second and third parts, by introducing other parameters, alternative equivalent dependences of the final relationship have been developed and variants of its approximation for application in computational practice are considered. In the fourth part, additional properties of the final relationship are considered, the possibility and necessity of its use in problems of plastic deformation of plates and shells is shown.
\end{abstract}

Keywords: the plasticity theory, plastic deformation of plates and shells, surface of fluidity, plasticity condition

\section{КОНЕЧНОЕ СООТНОШЕНИЕ А.А. ИЛЬЮШИНА, АЛЬТЕРНАТИВНЫЕ ЭКВИВАЛЕНТНЫЕ ЗАВИСИМОСТИ И ВАРИАНТЫ ЕГО АППРОКСИМАЦИИ В ЗАДАЧАХ ПЛАСТИЧЕСКОГО ДЕФОРМИРОВАНИЯ ПЛАСТИН И ОБОЛОЧЕК \\ ЧАСТЬ 1: КОНЕЧНОЕ СООТНОШЕНИЕ А.А. ИЛЬЮШИНА}

\author{
А.В. Старов, С.Ю. Калашников \\ Волгоградский государственный технический университет, г. Волгоград, РОССИЯ
}

\begin{abstract}
Аннотация: Выполнено исследование конечного соотношения между силами и моментами пластин и оболочек в параметрическом виде теории малых упругопластических деформаций А.А. Ильюшина, для определения несущей способности конструкций из материала без упрочнения. Получен геометрический образ точной поверхности текучести в пространстве обобщенных напряжений. В первой части статьи приводится вывод конечного соотношения. Во второй и третьей частях введением других параметров разработаны альтернативные эквивалентные зависимости конечного соотношения и рассмотрены варианты его аппроксимации для применения в расчетной практике. В четвертой части рассмотрены дополнительные свойства конечного соотношения, показана возможность и необходимость его использования в задачах пластического деформирования пластин и оболочек.
\end{abstract}

Ключевые слова: теория пластичности, пластическое деформирование пластин и оболочек, поверхность текучести, условия пластичности 
A.A. Ilyushin's Final Relation, Alternative Equivalent Relations and Versions of Uts Approximation in Problems of Plastic Deformation of Plates and Shells. Part 1: A.A. Ilyushin's Final Relation

\section{INTRODUCTION}

Theory of small elastoplastic deformations Ilyushin was created in connection with the problem of the strength of the projectile while moving in the barrel of the gun. All calculations were carried out by the methods of the theory of elasticity, although a small residual plastic deformation was allowed by normative documents. Together with theorems on simple loading, unloading, and the method of elastic solutions, the theory of A.A. Ilyushin was a powerful apparatus for investigating the strength, deformability and stability of structural elements, structures and machine parts beyond the elastic limit. [1-8]

The theory of elastoplastic deformations of plates and shells is presented by A.A. Ilyushin in [9-14], where on the basis of the methods of the theory of plasticity a finite relationship between forces and moments was obtained to determine the load-bearing capacity of structures from a material without hardening and the limiting state is characterized by the propagation of fluidity throughout the volume.

Since the equations of the theory of plates and shells are formulated in generalized forces and generalized displacements, the conditions of strength and plasticity must also be represented in generalized forces. The transformation of the condition of strength and plasticity from the stress space into the space of generalized stresses is one of the most important and complex problems of the theory of limiting equilibrium of plates and shells [15-16].

The parametric equation of the limiting hypersurface in generalized stresses for thin plates and shells on the basis of the Mizes condition of plasticity and the relations of the theory of small elastoplastic deformations was first obtained by A.A. Ilyushin $[9,13]$. The traditional KirchhoffLove hypotheses and the incompressibility of the material are used. Received A.A. Ilyushin's relations are not expressed in explicit form and are complex for solving practical problems. The geometrical image of the exact yield surface in the literature is absent.

Similar relations with the introduction of other parameters were obtained in the works of V.V. Rozhdestvensky [17], G.S. Shapiro [18], P.G. Hodge [19-22], D.C. Drucker, H.G. Hopkins [23], D.C. Drucker [24], D.C. Drucker, R.T. Shield [25], E.T. Onat [26,28], E.T. Onat, W. Prager [27] and other authors. Detailed reviews of literature on this topic can be found in [1516], as well as in the works of N. Jones [29-30] and Yu.V. Nemirovsky, TP Romanova [31].

In the works of M.I. Erhov [32-33], on the basis of the two-layer cross section model and the flow conditions of R. Mizes, a finite relationship between the internal forces and the moments of ideally plastic plates and shells is obtained on the assumption that the strain intensity within the layer is constant in the plastic region. Here is a schematic model of the exact yield surface and the proposed version of its approximation. A similar model of the approximation of the cross-section of a homogeneous shell by a twolayered cross section was used by V.I. Rosenblum [34-37], Yu.N. Rabotnov [38]. This approach and its various variants were used by other authors.

If the shell material is ideally plastic and satisfies to a condition of fluidity of Mizes, for a plastic condition $\sigma_{i}=\sigma_{s}=$ const . In this case in purely plastic areas of a shell the right parts of determining relations for the generalised pressure will be uniform functions of a zero order concerning six parametres $\varepsilon_{i}, \chi_{i}$.

From this necessity of existence of a final relation which plays a role of a condition of fluidity follows and connects values of efforts and the moments in purely plastic areas of a shell $[9,39]$. Owing to noted property of uniformity of the equations in purely plastic areas $\varepsilon_{i}, \chi_{i}$ it is possible to replace deformation components $\varepsilon_{i}, \chi_{i}$ in the corresponding speeds $\dot{\varepsilon}_{i}, \dot{\chi}_{i}$.

The definition of the ultimate load reduces to the construction of internal stress fields, moments, displacements, and velocities of dis- 
placements of the middle surface that satisfy equilibrium equations in the plastic regions, the final relationship, the dependencies between the velocities of displacements of the middle surface and the deformation rates that determine the relations for generalized stresses. In rigid regions, the velocities must vanish or correspond with the rigid displacement with joints, and the forces and moments must satisfy the equilibrium conditions and do not contradict the final relation. The specified static and kinematic boundary conditions must also be satisfied [9, 39].

The final relation corresponding to the defining equations [9] has a very complex structure and is not explicitly expressed. For an approximate analysis, it is approximated by a quadratic dependence [9-10,32-37], which corresponds to the particular case [9], while the bilinear form

$$
\begin{aligned}
P_{\varepsilon \chi}= & \varepsilon_{1} \chi_{1}+\varepsilon_{2} \chi_{2}+\frac{1}{2} \varepsilon_{1} \chi_{2}+\frac{1}{2} \varepsilon_{2} \chi_{1}+\varepsilon_{11} \chi_{12}=0: \\
& \frac{1}{N_{s}^{2}}\left(N_{1}^{2}-N_{1} N_{2}+N_{2}^{2}+3 N_{12}^{2}\right)+ \\
& +\frac{1}{N_{s}^{2}}\left(M_{1}^{2}-M_{1} M_{2}+M_{2}^{2}+3 M_{12}^{2}\right)=1, \\
& N_{s}=\sigma_{s} h, \quad M_{s}=\frac{\sigma_{s} h^{2}}{4} .
\end{aligned}
$$

For the axisymmetric problem, the following approximations are also used.

1. A semilinear final relation [19, 32-37], which corresponds to the linearization of the previous relation

$$
\begin{aligned}
& n^{2}+m^{2}=1, n=\max \left\{\left|\frac{N_{1}}{N_{s}}\right|,\left|\frac{N_{2}}{N_{s}}\right|,\left|\frac{N_{1}-N_{2}}{N_{s}}\right|\right\}, \\
& m=\max \left\{\left|\frac{M_{1}}{M_{s}}\right|,\left|\frac{M_{2}}{M_{s}}\right|,\left|\frac{M_{1}-M_{2}}{M_{s}}\right|\right\} .
\end{aligned}
$$

2. The final relationship with a limited interaction of forces and moments [19, 32-37], which does not take into account the interaction of membrane and bending force factors, and others. The degree of approximation of these relations to the exact one [9] depends on the ratio $0 \leq P_{\varepsilon \chi}^{2} \leq P_{\varepsilon} \cdot P_{\chi}$. Meanwhile, elementary analysis shows that in the center of a flexible circular plate or a slender axisymmetric shell is always satisfied $P_{\varepsilon \chi}^{2}=P_{\varepsilon} \cdot P_{\chi} \neq 0$.

In the works of V.I. Korolev [40] and P.M. Ogibalov [41] deduces the derivation of the finite relation AA. Ilyushin and solve the problem for the simplest complex stress state of shells at $P_{\chi} \neq 0, P_{\varepsilon} \neq 0, P_{\varepsilon \chi}=0$.

The purpose of this article is to investigate the final relationship of AA. Ilyushin, obtaining a geometric image of the exact yield surface, alternative dependencies and variants of its approximation.

In the first part of the paper, with some abbreviations, the derivation of the final relation presented in \$24-26 [9] is given. In contrast to [9], the designations of stresses, forces and shear forces in the shell sections have been changed $\sigma_{x}, \sigma_{y}, \sigma_{z}, \tau_{x y}, \tau_{z x}, \tau_{z y}$ $N_{1}, N_{2}, N_{12}, n_{1}, n_{2}, n_{12}, Q_{1}, Q_{2}$, while the numbering of formulas, tables, graphs and references to formulas are completely preserved. In the second and third parts, alternative equivalent dependencies of the final relationship are developed and variants of its approximation are considered for application in computational practice. In the fourth part, additional properties of the final relationship are considered, the possibility and necessity of its use in problems of plastic deformation of plates and shells is shown.

1.1. The connection between internal forces, moments and deformations of the shell on the basis of the theory of small elastoplastic deformations Intensity of deformations, according to (4.7): 
A.A. Ilyushin's Final Relation, Alternative Equivalent Relations and Versions of Uts Approximation in Problems of Plastic Deformation of Plates and Shells. Part 1: A.A. Ilyushin's Final Relation

$$
\begin{aligned}
& e_{i}=\frac{2}{\sqrt{3}} \sqrt{P_{\varepsilon}-2 z P_{\varepsilon \chi}+z^{2} P_{\chi}}, \\
& P_{\varepsilon}=\varepsilon_{1}^{2}+\varepsilon_{1} \varepsilon_{2}+\varepsilon_{2}^{2}+\varepsilon_{12}^{2}, P_{\chi}=\chi_{1}^{2}+\chi_{1} \chi_{2}+\chi_{2}^{2}+\chi_{12}^{2}, \\
& P_{\varepsilon \chi}=\varepsilon_{1} \chi_{1}+\varepsilon_{2} \chi_{2}+\frac{1}{2} \varepsilon_{1} \chi_{2}+\frac{1}{2} \varepsilon_{2} \chi_{1}+\varepsilon_{11} \chi_{12} .
\end{aligned}
$$

The stresses according to (4.2):

$$
\begin{aligned}
& S_{x}=\sigma_{x}-\frac{1}{2} \sigma_{y}=\frac{\sigma_{i}}{e_{i}}\left(\varepsilon_{1}-z \chi_{1}\right), \\
& S_{y}=\sigma_{y}-\frac{1}{2} \sigma_{x}=\frac{\sigma_{i}}{e_{i}}\left(\varepsilon_{2}-z \chi_{2}\right), \\
& S_{x y}=\tau_{x y}=\frac{2 \sigma_{i}}{3 e_{i}}\left(\varepsilon_{12}-z \chi_{12}\right),
\end{aligned}
$$

And $\sigma_{i}$ there is a certain function $e_{i}$, the voltage $\tau_{x z}, \tau_{y z}, \sigma_{z}$ is small in comparison with the main ones. If the shell is thin enough and the ratio of its thickness to the characteristic radius of curvature can be neglected, we obtain the following five expressions for the forces:

$$
\begin{aligned}
& N_{1}=\int_{-\frac{h}{2}}^{\frac{h}{2}} \sigma_{x} d z, N_{2}=\int_{-\frac{h}{2}}^{\frac{h}{2}} \sigma_{y} d z, N_{12}=\int_{-\frac{h}{2}}^{\frac{h}{2}} \tau_{x y} d z, \\
& Q_{1}=\int_{-\frac{h}{2}}^{\frac{h}{2}} \tau_{z x} d z, Q_{2}=\int_{-\frac{h}{2}}^{\frac{h}{2}} \tau_{z y} d z .
\end{aligned}
$$

The shearing forces $Q_{1}, Q_{2}$, despite the small stresses $\tau_{z x}, \tau_{z y}$, are not equal to zero, and are determined from the equilibrium equations. Similarly, one can write formulas for bending and twisting moments

$$
M_{1}=\int_{-\frac{h}{2}}^{\frac{h}{2}} \sigma_{x} z d z, M_{2}=\int_{-\frac{h}{2}}^{\frac{h}{2}} \sigma_{y} z d z, M_{12}=\int_{-\frac{h}{2}}^{\frac{h}{2}} \tau_{x y} z d z .
$$

For simplification of calculations instead of forces $N_{1}, N_{2}, N_{12}$ it is convenient to enter their linear combinations

$$
\begin{aligned}
& S_{1}=N_{1}-\frac{1}{2} N_{2}=\int_{-\frac{h}{2}}^{\frac{h}{2}} S_{x} d z, S_{2}=N_{2}-\frac{1}{2} N_{1}=\int_{-\frac{h}{2}}^{\frac{h}{2}} S_{y} d z, \\
& \frac{2}{3} S_{12}=N_{12}=\int_{-\frac{h}{2}}^{\frac{h}{2}} S_{x y} d z,
\end{aligned}
$$

And instead of the moments $M_{1}, M_{2}, M_{12}$ of their combination

$$
\begin{aligned}
& H_{1}=M_{1}-\frac{1}{2} M_{2}=\int_{-\frac{h}{2}}^{\frac{h}{2}} S_{x} z d z, \\
& H_{2}=M_{2}-\frac{1}{2} M_{1}=\int_{-\frac{h}{2}}^{\frac{h}{2}} S_{y} z d z, \\
& \frac{2}{3} H_{12}=M_{12}=\int_{-\frac{h}{2}}^{\frac{h}{2}} S_{x y} z d z .
\end{aligned}
$$

From (4.23) and (4.20) we have: 


$$
\begin{aligned}
& S_{1}=\varepsilon_{1} \int_{-\frac{h}{2}}^{\frac{h}{2}} \frac{\sigma_{i}}{e_{i}} d z-\chi_{1} \int_{-\frac{h}{2}}^{\frac{h}{2}} \frac{\sigma_{i}}{e_{i}} z d z, \\
& S_{2}=\varepsilon_{2} \int_{-\frac{h}{2}}^{\frac{h}{2}} \frac{\sigma_{i}}{e_{i}} d z-\chi_{2} \int_{-\frac{h}{2}}^{\frac{h}{2}} \frac{\sigma_{i}}{e_{i}} z d z, \\
& S_{12}=\varepsilon_{12} \int_{-\frac{h}{2}}^{\frac{h}{2}} \frac{\sigma_{i}}{e_{i}} d z-\chi_{12} \int_{-\frac{h}{2}}^{\frac{h}{2}} \frac{\sigma_{i}}{e_{i}} z d z,
\end{aligned}
$$

And from (4.24) we have:

$$
\begin{aligned}
& H_{1}=\varepsilon_{1} \int_{-\frac{h}{2}}^{\frac{h}{2}} \frac{\sigma_{i}}{e_{i}} z d z-\chi_{1} \int_{-\frac{h}{2}}^{\frac{h}{2}} \frac{\sigma_{i}}{e_{i}} z^{2} d z, \\
& H_{2}=\varepsilon_{2} \int_{-\frac{h}{2}}^{\frac{h}{2}} \frac{\sigma_{i}}{e_{i}} z d z-\chi_{2} \int_{-\frac{h}{2}}^{\frac{h}{2}} \frac{\sigma_{i}}{e_{i}} z^{2} d z, \\
& H_{12}=\varepsilon_{12} \int_{-\frac{h}{2}}^{\frac{h}{2}} \frac{\sigma_{i}}{e_{i}} z d z-\chi_{12} \int_{-\frac{h}{2}}^{\frac{h}{2}} \frac{\sigma_{i}}{e_{i}} z^{2} d z .
\end{aligned}
$$

In formulas $(4.23$ ') and (4.24'), there are three types of integrals that are common in shell thickness:

$$
J_{1}=\int_{-\frac{h}{2}}^{\frac{h}{2}} \frac{\sigma_{i}}{e_{i}} d z, J_{2}=\int_{-\frac{h}{2}}^{\frac{h}{2}} \frac{\sigma_{i}}{e_{i}} z d z, J_{3}=\int_{-\frac{h}{2}}^{\frac{h}{2}} \frac{\sigma_{i}}{e_{i}} z^{2} d z .
$$

Through them the forces and moments are expressed:

$$
\begin{aligned}
& \frac{3}{4} N_{1}=\left(\varepsilon_{1}+\frac{1}{2} \varepsilon_{2}\right) J_{1}-\left(\chi_{1}+\frac{1}{2} \chi_{2}\right) J_{2} \\
& \frac{3}{4} N_{2}=\left(\varepsilon_{2}+\frac{1}{2} \varepsilon_{1}\right) J_{1}-\left(\chi_{2}+\frac{1}{2} \chi_{1}\right) J_{2},(4 \\
& \frac{3}{2} N_{12}=\varepsilon_{12} J_{1}-\chi_{12} J_{2} \\
& \frac{3}{4} M_{1}=\left(\varepsilon_{1}+\frac{1}{2} \varepsilon_{2}\right) J_{2}-\left(\chi_{1}+\frac{1}{2} \chi_{2}\right) J_{3} \\
& \frac{3}{4} M_{2}=\left(\varepsilon_{2}+\frac{1}{2} \varepsilon_{1}\right) J_{2}-\left(\chi_{2}+\frac{1}{2} \chi_{1}\right) J_{3},(
\end{aligned}
$$$$
\frac{3}{2} M_{12}=\varepsilon_{12} J_{2}-\chi_{12} J_{3} \text {. }
$$

Since in (4.25) $\sigma_{i}$ there is a given function of $e_{i}$, and its form for each material becomes known in particular problems, it is natural to get rid of integration with respect to $z$ and proceed from (4.19) to integrate over $e_{i}$.

Multiplying $J_{1}$ by $P_{\varepsilon}, J_{2}$ by $-2 P_{\varepsilon \chi}, J_{3}$ by $J_{3}$ $P_{\chi}$ and by adding the results, we get:

$$
J_{1} P_{\varepsilon}-2 J_{2} P_{\varepsilon \chi}+J_{3} P_{\chi}=\frac{3}{4} \int_{-\frac{h}{2}}^{\frac{h}{2}} \sigma_{i} e_{i} d z
$$

Differentiating (4.19) with respect to $z$, we find:

$$
\frac{3}{4} e_{i} d e_{i}=\left(z P_{\chi}-P_{\varepsilon \chi}\right) d z
$$

Multiply no $J_{1}$ by $-2 P_{\varepsilon \chi}$ and $J_{2}$ on $P_{\chi}$ and add the results, then we get:

$$
-J_{1} P_{\varepsilon \chi}+J_{2} P_{\chi}=\frac{3}{4} \int \sigma_{i} d e_{i}
$$

We find the expression $z^{2}$ by $e_{i}$, for this it is necessary to solve the quadratic equation (4.19) 
A.A. Ilyushin's Final Relation, Alternative Equivalent Relations and Versions of Uts Approximation in Problems of Plastic Deformation of Plates and Shells. Part 1: A.A. Ilyushin's Final Relation

$$
z^{2} P_{\chi}-2 z P_{\varepsilon \chi}+P_{\varepsilon}=\frac{3}{4} e_{i}^{2},
$$

Which root which is not contradicting a relation (4.29), is

$$
z=\frac{P_{\varepsilon \chi}}{P_{\chi}}+\frac{\sqrt{3}}{2 \sqrt{P_{\chi}}} \sqrt{e_{i}^{2}-\frac{4}{3} \frac{P_{\varepsilon} P_{\chi}-P_{\varepsilon \chi}^{2}}{P_{\chi}}} \cdot \operatorname{sign}\left(z P_{\chi}-P_{\varepsilon \chi}\right),
$$

And it is always necessary to take a positive value of the square root. Differentiating (4.31), we obtain:

$$
d z=\frac{\sqrt{3}}{2 \sqrt{P_{\chi}}} \frac{e_{i} d e_{i} \cdot \operatorname{sign} d e_{i}}{\sqrt{e_{i}^{2}-\frac{4}{3} \frac{P_{\varepsilon} P_{\chi}-P_{\varepsilon \chi}^{2}}{P_{\chi}}}} .
$$

The value sign $z P_{\chi}-P_{\varepsilon \chi}$, according to (4.29), coincides with a sign $\frac{d e_{i}}{d z}$ and as in intervals interesting us $d z$ always it is positive at change $z$

$$
\text { from }-\frac{h}{2} \text { to }+\frac{h}{2}
$$

integration on $d e_{i}$ should be executed so that $d e_{i}$ too increased, i.e. it is necessary to integrate on $d e_{i} \cdot \operatorname{sign} d e_{i}$.

Let's consider values of intensity of deformations in three points on an axis $z$ :

$$
z=-\frac{h}{2}, \quad z=+\frac{h}{2}, \quad z=z_{0}, \quad z_{0}=\frac{P_{\varepsilon \chi}}{P_{\chi}}
$$

Let's designate them accordingly:

$$
\begin{aligned}
& e_{i 1}=\frac{2}{\sqrt{3}} \sqrt{P_{\varepsilon}+h P_{\varepsilon \chi}+\frac{h^{2}}{4} P_{\chi}} \quad\left(z=-\frac{h}{2}\right), \\
& e_{i 2}=\frac{2}{\sqrt{3}} \sqrt{P_{\varepsilon}-h P_{\varepsilon \chi}+\frac{h^{2}}{4} P_{\chi}} \quad\left(z=+\frac{h}{2}\right), \\
& e_{i 0}=\frac{2}{\sqrt{3} \sqrt{P_{\chi}}} \sqrt{P_{\varepsilon} P_{\chi}-P_{\varepsilon \chi}^{2}} \quad\left(z=z_{0}\right) .
\end{aligned}
$$

Apparently from (4.29), the point $z=z_{0}$ is a minimum point $e_{i}$. Hence, inequalities always take place

$$
e_{i 1} \geq e_{i 0}, e_{i 2} \geq e_{i 0} \text {. }
$$

We shall say that the deformations of the stretching and the shift of the middle surface $\varepsilon_{1}, \varepsilon_{2}, \varepsilon_{12}$ are commensurable or small in comparison with deformations of the bending of the shell

$$
\pm \frac{h}{2} \chi_{1}, \pm \frac{h}{2} \chi_{2}, \pm \frac{h}{2} \chi_{12}
$$

or that the latter are dominant if the point $z_{0}$ does not exceed the thickness of the shell

$$
-\frac{h}{2} \leq z_{0}=\frac{P_{\varepsilon \chi}}{P_{\chi}} \leq \frac{h}{2}
$$

Deformations of the middle surface will be called large or dominant as compared with deformation of the bend if the point is located outside the thickness of the shell, that is, if one of the inequalities holds

$$
z_{0}=\frac{P_{\varepsilon \chi}}{P_{\chi}}>\frac{h}{2}, \quad z_{0}=\frac{P_{\varepsilon \chi}}{P_{\chi}}<-\frac{h}{2} .
$$

In case of commensurable tensile deformations and a bending, the integral from any positive 
value $R$ on a thickness of a shell is necessary for calculating under the formula:

$$
\int_{-\frac{h}{2}}^{\frac{h}{2}} R d z=\frac{\sqrt{3}}{2 \sqrt{P_{\chi}}}\left[\int_{e_{i 0}}^{e_{i 1}} \frac{R e_{i} d e_{i}}{\sqrt{e_{i}^{2}-e_{i 0}^{2}}}+\int_{e_{i 0}}^{e_{i 2}} \frac{R e_{i} d e_{i}}{\sqrt{e_{i}^{2}-e_{i 0}^{2}}}\right] .
$$

In case of incommensurable or large tensile deformations such integral should be calculated under the formula:

$$
\int_{-\frac{h}{2}}^{\frac{h}{2}} R d z=\frac{\sqrt{3} \cdot \operatorname{sign}\left(e_{i 2}-e_{i 1}\right)}{2 \sqrt{P_{\chi}}} \int_{e_{i 1}}^{e_{i 2}} \frac{R e_{i} d e_{i}}{\sqrt{e_{i}^{2}-e_{i 0}^{2}}} .
$$

We introduce the notation of the principal quantities in the theory of shells:

$$
\begin{aligned}
& A=A_{0}, B=B_{0}, C=C_{0}\left(-\frac{h}{2} \leq z_{0} \leq \frac{h}{2}\right), \\
& A=A_{1}, B=B_{1}, C=C_{1}\left(\left|z_{0}\right|>\frac{h}{2}\right),
\end{aligned}
$$

Where the values $A_{0}, B_{0}, C_{0}$ refer to the case of the dominant deformation of the bending and are equal to:

$$
\begin{aligned}
& A_{0}=-\int_{e_{i 0}}^{e_{i 1}} \sigma_{i} d e_{i}+\int_{e_{i 0}}^{e_{i 2}} \sigma_{i} d e_{i}=\int_{e_{i 1}}^{e_{i 2}} \sigma_{i} d e_{i}, \\
& B_{0}=\int_{e_{i 0}}^{e_{i 1}} \frac{\sigma_{i} d e_{i}}{\sqrt{e_{i}^{2}-e_{i 0}^{2}}}+\int_{e_{i 0}}^{e_{i 2}} \frac{\sigma_{i} d e_{i}}{\sqrt{e_{i}^{2}-e_{i 0}^{2}}}, \\
& C_{0}=\int_{e_{i 0}}^{e_{i 1}} \sigma_{i} \sqrt{e_{i}^{2}-e_{i 0}^{2}} d e_{i}+\int_{e_{i 0}}^{e_{i 2}} \sigma_{i} \sqrt{e_{i}^{2}-e_{i 0}^{2}} d e_{i} .
\end{aligned}
$$

And $A_{1}, B_{1}, C_{1}$ concern to a case of a dominating stretching of a median surface and are equal:
$A_{0}=A_{1}=\int_{e_{i 1}}^{e_{i 2}} \sigma_{i} d e_{i}, \quad B_{1}=\int_{e_{i 1}}^{e_{i 2}} \frac{\sigma_{i} d e_{i}}{\sqrt{e_{i}^{2}-e_{i 0}^{2}}} \cdot \operatorname{sign}\left(e_{i 2}-e_{i 1}\right)$,

$C_{1}=\int_{e_{i 1}}^{e_{i 2}} \sigma_{i} \sqrt{e_{i}^{2}-e_{i 0}^{2}} d e_{i} \cdot \operatorname{sign}\left(e_{i 2}-e_{i 1}\right)$.

$J_{1}, J_{2}, J_{3}\left(4.23^{\prime}\right),\left(4.24^{\prime}\right),(4.26)$ and (4.27), it is possible to express the integrals $J_{1}, J_{2}, J_{3}$ entering in the formulas through the basic values $A, B, C$ depending on the basic quadratic forms $P_{\varepsilon}, P_{\chi}, P_{\varepsilon \chi}$, according to formulas (4.37). For this purpose we notice that the integral $J_{1}$ on the basis of formulas (4.25) and (4.35')(4.36') is directly expressed through function $B$ then from (4.30) it is found $J_{2}$ through $A$ and $B$, after from (4.28) is received $J_{3}$ through $A, B, C$. Thus we find following formulas:

$$
\begin{aligned}
J_{1}= & \frac{\sqrt{3}}{2 P_{\chi}^{\frac{1}{2}}} B, J_{2}=\frac{\sqrt{3} P_{\varepsilon \chi}}{2 P_{\chi}^{\frac{3}{2}}} B+\frac{3}{4 P_{\chi}} A, \\
J_{3}= & \frac{3 \sqrt{3}}{8 P_{\chi}^{\frac{3}{2}}} C+\frac{\sqrt{3} P_{\varepsilon \chi}^{2}}{2 P_{\chi}^{\frac{5}{2}}} B+\frac{3 P_{\varepsilon \chi}}{2 P_{\chi}^{2}} A .
\end{aligned}
$$

Values $A, B, C$ need to attribute an index «0» and to calculate them under formulas (4.37') if bending strain dominates or to attribute an index «1» and to calculate according to (4.37 ") if the stretching-compression of a middle surface dominates.

The formula (4.32) and all subsequent calculations lose their meaning when the momentless state is stressful, when the quantities $e_{i}$ and $\sigma_{i}$ are constant in thickness. In this case

$$
P_{\chi}=P_{\varepsilon \chi}=0, e_{i}=\frac{2}{\sqrt{3}} \sqrt{P_{\varepsilon}},
$$


A.A. Ilyushin's Final Relation, Alternative Equivalent Relations and Versions of Uts Approximation in Problems of Plastic Deformation of Plates and Shells. Part 1: A.A. Ilyushin's Final Relation

And the integrals $J_{1}, J_{2}, J_{3}$ can be calculated directly. From the formulas (4.25) we have:

$$
J_{1}=h \frac{\sigma_{i}}{e_{i}}, J_{2}=0, J_{3}=\frac{h^{3}}{12} \frac{\sigma_{i}}{e_{i}}
$$

As equality

$$
P_{\chi}=0
$$

is possible only at

$$
\chi_{1}=\chi_{2}=\chi_{12}=0
$$

all bending moments are equal to zero.

The relations (4.23'), (4.24') or (4.26), (4.27) give the expressions for the forces and moments acting on the shell element through three quadratic forms $P_{\varepsilon}, P_{\chi}, P_{\varepsilon \chi}$ :

$P_{\varepsilon}=\varepsilon_{1}^{2}+\varepsilon_{1} \varepsilon_{2}+\varepsilon_{2}^{2}+\varepsilon_{12}^{2}, P_{\chi}=\chi_{1}^{2}+\chi_{1} \chi_{2}+\chi_{2}^{2}+\chi_{12}^{2}$, $P_{\varepsilon \chi}=\varepsilon_{1} \chi_{1}+\varepsilon_{2} \chi_{2}+\frac{1}{2} \varepsilon_{1} \chi_{2}+\frac{1}{2} \varepsilon_{2} \chi_{1}+\varepsilon_{12} \chi_{12}$

And six components of deformations and distortions $\varepsilon_{1}, \varepsilon_{2}, \varepsilon_{12}, \chi_{1}, \chi_{2}, \chi_{12}$, hence through the three components of the displacement vector of the point of the middle surface, since deformations and curvatures have differential expressions through $u, v, w$.

We show that all deformations and curvatures can be expressed in terms of forces and moments. To do this, we find the expressions for the quadratic forms (4.43) in terms of analogous quadratic forms of forces and moments. According to the expressions $S, H$, through $T, M$ (4.23)-(4.24) we have the identities:

$$
\begin{aligned}
& P_{S}=S_{1}^{2}+S_{1} S_{2}+S_{2}^{2}+3 S_{12}^{2}= \\
& =\frac{3}{4}\left(N_{1}^{2}-N_{1} N_{2}+N_{2}^{2}+3 N_{12}^{2}\right) \\
& P_{H}=H_{1}^{2}+H_{1} H_{2}+H_{2}^{2}+3 H_{12}^{2}= \\
& =\frac{3}{4}\left(M_{1}^{2}-M_{1} M_{2}+M_{2}^{2}+3 M_{12}^{2}\right), \\
& P_{S H}=S_{1} H_{1}+S_{2} H_{2}+\frac{1}{2} S_{1} H_{2}+\frac{1}{2} S_{2} H_{1}+ \\
& +3 S_{12} H_{12}= \\
& =\frac{3}{4}\left(\begin{array}{l}
\left.N_{1} M_{1}+N_{2} M_{2}-\frac{1}{2} N_{1} M_{2}-\frac{1}{2} N_{2} M_{1}+\right) . \\
+3 N_{12} M_{12}
\end{array}\right.
\end{aligned}
$$

We form the quadratic forms $P_{S}, P_{H}, P_{S H}$ according to relations (4.23') and (4.24'), replacing the integrals entering them by the notation (4.25) by $J_{1}, J_{2}, J_{3}$.

From the group of equations (4.23') we have:

$$
P_{S}=J_{1}^{2} P_{\varepsilon}-2 J_{1} J_{2} P_{\varepsilon \chi}+J_{2}^{2} P_{\chi} .
$$

Similarly, from the group of equations (4.24') we find:

$$
P_{H}=J_{2}^{2} P_{\varepsilon}-2 J_{2} J_{3} P_{\varepsilon \chi}+J_{3}^{2} P_{\chi} .
$$

Constructing from both groups of equations (4.23'), (4.24') a bilinear form $P_{S H}$ and collecting the coefficients of the products $J_{1}, J_{2}$ and $J_{2}, J_{3}$, we obtain:

$$
P_{S H}=J_{1} J_{2} P_{\varepsilon}-\left(J_{1} J_{3}+J_{2}^{2}\right) P_{\varepsilon \chi}+J_{2} J_{3} P_{\chi} .
$$

As the left parts of relation (4.45) are known functions (4.44) forces and the moments, and right depend only from $P_{\varepsilon}, P_{\chi}, P_{\varepsilon \chi}$ as $J_{1}, J_{2}, J_{3}$ are expressed under formulas (4.38), (4.37), (4.34) relation (4.45) represent three algebraic 
equations from which it is possible to express forms $P_{\varepsilon}, P_{\chi}, P_{\varepsilon \chi}$ through $P_{S}, P_{H}, P_{S H}$ :

$$
\begin{aligned}
& P_{\varepsilon}=f_{1}\left(P_{S}, P_{H}, P_{S H}\right), P_{\chi}=f_{2}\left(P_{S}, P_{H}, P_{S H}\right), \\
& P_{\varepsilon \chi}=f_{3}\left(P_{S}, P_{H}, P_{S H}\right)
\end{aligned}
$$

Actually it can be executed after the particular characteristic of a material of a shell is given, i.e. the function kind is set $\sigma_{i}=\Phi\left(e_{i}\right)$.

Assuming that expressions (4.46) are found, we can find expressions of deformations $\varepsilon, \chi$ through forces $T, M$ or $S, H$. For this purpose it is necessary to substitute (4.46) in (4.38), to express $J_{1}, J_{2}, J_{3}$ through $P_{S}, P_{H}, P_{S H}$ and to decide the equations (4.23'), (4.24') rather $\varepsilon, \chi$. Thus, we receive definitive formulas:

$\varepsilon_{1}=\frac{1}{\Delta}\left(S_{1} J_{3}-H_{1} J_{2}\right), \chi_{1}=\frac{1}{\Delta}\left(S_{1} J_{2}-H_{1} J_{1}\right)$,

$\varepsilon_{2}=\frac{1}{\Delta}\left(S_{2} J_{3}-H_{2} J_{2}\right), \chi_{2}=\frac{1}{\Delta}\left(S_{2} J_{2}-H_{2} J_{1}\right)$,

$\varepsilon_{12}=\frac{1}{\Delta}\left(S_{12} J_{3}-H_{12} J_{2}\right), \chi_{12}=\frac{1}{\Delta}\left(S_{12} J_{2}-H_{12} J_{1}\right)$,

$\Delta=\left(J_{1} J_{3}-J_{2}^{2}\right)$.

\subsection{The final relationship between forces and moments and the formulation of the problem of the load-carrying capacity of shells}

If intensity of deformations $e_{i}$ (4.19) any layers of a shell is great enough in comparison with yield strength $e_{s}$, i.e.

$$
\frac{2}{\sqrt{3}} \sqrt{P_{\varepsilon}-2 z P_{\varepsilon \chi}+z^{2} P_{\chi}}=e_{i}>>e_{s},
$$

and its material does not possess hardening the law $\sigma_{i}=\Phi\left(e_{i}\right)$ coincides with a condition of plasticity of Mizes:

$$
\sigma_{i}=\sigma_{s}=\text { const. }
$$

Or can be approximately replaced by a condition of plasticity of Sen-Venan-Kulon:

$$
\tau_{\max }=\frac{\sigma_{s}}{\sqrt{3}}=\text { const }
$$

We show that in this case there exists a finite (not differential) relation between the forces and the moments. Using formulas (4.37), taking the integral sign as a constant $\sigma_{i}$, we can calculate the values of the functions $A, B, C$.

In the case of dominant bending deformations, the formulas (4.37') take the form:

$$
\begin{aligned}
& A_{0}=\sigma_{s}\left(e_{i 2}-e_{i 1}\right), \\
& B_{0}=\sigma_{s} \ln \frac{\left(e_{i 1}+\sqrt{e_{i 1}^{2}-e_{i 0}^{2}}\right)\left(e_{i 2}+\sqrt{e_{i 2}^{2}-e_{i 0}^{2}}\right)}{e_{i 0}^{2}}, \\
& C_{0}=\frac{\sigma_{s}}{2}\left(e_{i 1} \sqrt{e_{i 1}^{2}-e_{i 0}^{2}}+e_{i 2} \sqrt{e_{i 2}^{2}-e_{i 0}^{2}}\right)-\frac{1}{2} e_{i 0}^{2} B_{0},
\end{aligned}
$$

and in case of dominating lengthening of a middle surface from formulas (4.37 ") it is found:

$$
\begin{aligned}
& A_{1}=\sigma_{s}\left(e_{i 2}-e_{i 1}\right), B_{1}=\sigma_{s}\left|\ln \frac{\left(e_{i 2}+\sqrt{e_{i 2}^{2}-e_{i 0}^{2}}\right)}{\left(e_{i 1}+\sqrt{e_{i 1}^{2}-e_{i 0}^{2}}\right)}\right|, \\
& C_{1}=\frac{\sigma_{s}}{2}\left|e_{i 2} \sqrt{e_{i 2}^{2}-e_{i 0}^{2}}-e_{i 1} \sqrt{e_{i 1}^{2}-e_{i 0}^{2}}\right|-\frac{e_{i 0}^{2}}{2} B_{1} .
\end{aligned}
$$

In both cases of value $e_{i 1}, e_{i 2}, e_{i 0}$ are expressed by formulas (4.34). Considering the last as the equations concerning three quadratic forms $P_{\chi}, P_{\varepsilon \chi}, P_{\varepsilon}$, we copy them in a kind: 
A.A. Ilyushin's Final Relation, Alternative Equivalent Relations and Versions of Uts Approximation in Problems of Plastic Deformation of Plates and Shells. Part 1: A.A. Ilyushin's Final Relation

$$
\begin{aligned}
& P_{\varepsilon}+h P_{\varepsilon \chi}+\frac{h^{2}}{4} P_{\chi}=\frac{3}{4} e_{i 1}^{2}, P_{\varepsilon}-h P_{\varepsilon \chi}+\frac{h^{2}}{4} P_{\chi}=\frac{3}{4} e_{i 2}^{2}, \\
& P_{\varepsilon} P_{\chi}-P_{\varepsilon \chi}^{2}=\frac{3}{4} e_{i 0}^{2} P_{\chi} .
\end{aligned}
$$

Solving them with respect to quadratic forms leads to the following results:

$$
\begin{aligned}
& h P_{\varepsilon \chi}=\frac{3}{8}\left(e_{i 1}^{2}-e_{i 2}^{2}\right), P_{\varepsilon}=\frac{3}{8}\left(e_{i 1}^{2}+e_{i 2}^{2}\right)-\frac{h^{2}}{4} P_{\chi}, \\
& \frac{h^{2}}{4} P_{\chi}=\frac{3}{16}\left(\sqrt{e_{i 1}^{2}-e_{i 0}^{2}} \pm \sqrt{e_{i 2}^{2}-e_{i 0}^{2}}\right)^{2} .
\end{aligned}
$$

To determine the sign in the last formula, we use inequalities (4.35) and (4.36). In the case of the dominant bending strain from (4.35), we have:

$$
-2 \cdot \frac{h^{2}}{4} P_{\chi} \leq h P_{\varepsilon \chi} \leq 2 \cdot \frac{h^{2}}{4} P_{\chi}
$$

This inequality will take place, if in the formula (4.60) for $P_{\chi}$ in brackets to take a sign $(+)$. The inequality (4.36) will take place, if for $P_{\chi}$ in brackets to take a sign $(-)$.

Below, in all formulas with two signs, the upper sign will refer to the case of the dominant bending of the shell, and the lower sign to the case of the dominant extension-compression.

We introduce two basic parameters $\lambda$ and $\mu$ :

$$
\lambda=\frac{e_{i 2}}{e_{i 1}}, \mu=\frac{e_{i 0}}{e_{i 1}} .
$$

These parameters satisfy the following conditions:

$$
0 \leq \lambda \geq \mu \leq 1,
$$

Since $e_{i 0}-$ is the minimum value of the strain intensity at a given point of the shell. Then the formulas (4.60) can be rewritten in the form:

$$
P_{\chi}=\frac{3 e_{i 1}^{2}}{4 h^{2}} \Delta_{1}^{2}, P_{\varepsilon \chi}=\frac{3 e_{i 1}^{2}}{8 h} \Delta \Delta_{1}, P_{\varepsilon}=\frac{3 e_{i 1}^{2}}{16}\left(4 \mu^{2}+\Delta^{2}\right),
$$

where $\Delta_{1}$ and $\Delta$ designate following functions:

$$
\Delta_{1}=\left|\sqrt{1-\mu^{2}} \pm \sqrt{\lambda^{2}-\mu^{2}}\right|, \Delta=\frac{1-\lambda^{2}}{\Delta_{1}} .
$$

The kind of the formula (4.62) for $P_{\varepsilon}$ becomes clear if to take into consideration identity:

$4 \mu^{2}+\Delta^{2}=1+\lambda^{2}+2 \mu^{2} \mp 2 \sqrt{\left(1-\mu^{2}\right)\left(\lambda^{2}-\mu^{2}\right)}$.

Using the notation $\lambda, \mu$ and the established rule for applying two-valued formulas, we can rewrite the expressions for the functions $A, B, C$ (4.59) in the form:

$$
\begin{aligned}
& A=\sigma_{s} e_{i 1} \varphi(\lambda, \mu), B=\sigma_{s} \psi(\lambda, \mu), \\
& C=\frac{\sigma_{s}}{2} e_{i 1}^{2}\left[\chi(\lambda, \mu)-\mu^{2} \psi(\lambda, \mu)\right],
\end{aligned}
$$

Functions $\varphi, \psi$ also $\chi$ are determined so:

$$
\begin{aligned}
& \varphi=\lambda-1, \psi=\left|\ln \frac{1+\sqrt{1-\mu^{2}}}{\mu} \pm \ln \frac{\lambda+\sqrt{\lambda^{2}-\mu^{2}}}{\mu}\right|, \\
& \chi=\left|\sqrt{1-\mu^{2}} \pm \lambda \sqrt{\lambda^{2}-\mu^{2}}\right| .
\end{aligned}
$$

Using formulas (4.62) and (4.64), we can be convinced that quadratic forms $P_{S}, P_{H}, P_{S H}$, according to formulas (4.45) and (4.38), do not depend on value $e_{i 1}$ and are functions only parametres $\lambda, \mu$.

In this connection it is natural to introduce the 
notation for the characteristic value of forces $N_{1}, N_{2}, N_{12}$ and moments $M_{1}, M_{2}, M_{12}$ :

$$
N_{s}=\sigma_{s} h, M_{s}=\frac{\sigma_{s} h^{2}}{4} .
$$

The quantities $N_{s}, M_{s}$ in the problems of momentless deformations of shells and problems of purely moment deformations play the same role as the yield stress $\sigma_{s}$ in the plane stress problem. Therefore, it is useful to introduce the notation for dimensionless forces and moments:

$$
\begin{array}{ll}
n_{1}=\frac{N_{1}}{N_{s}}, & n_{2}=\frac{N_{2}}{N_{s}}, \quad n_{12}=\frac{N_{12}}{N_{s}}, \\
m_{1}=\frac{M_{1}}{M_{s}}, & m_{2}=\frac{M_{2}}{M_{s}},
\end{array}
$$

and instead of quadratic forms (4.44), consider quadratic forms of dimensionless forces and moments:

$$
\begin{aligned}
& Q_{n}=n_{1}^{2}-n_{1} n_{2}+n_{2}^{2}+3 n_{12}^{2}, \\
& Q_{m}=m_{1}^{2}-m_{1} m_{2}+m_{2}^{2}+3 m_{12}^{2}, \\
& Q_{n m}=n_{1} m_{1}+n_{2} m_{2}-\frac{1}{2} n_{1} m_{2}-\frac{1}{2} n_{2} m_{1}+3 n_{12} m_{12} .
\end{aligned}
$$

The last are connected with $P_{S}, P_{H}, P_{S H}$ obvious relation:

$$
Q_{n}=\frac{4 P_{S}}{3 N_{s}^{2}}, Q_{m}=\frac{4 P_{H}}{3 M_{s}^{2}}, Q_{n m}=\frac{4 P_{S H}}{3 N_{s} M_{s}} .
$$

Performing rather cumbersome transformations of the right-hand sides of equations (4.45), namely squaring polynomials and multiplying, and then collecting the coefficients for $\psi^{2}, \varphi^{2}, \varphi \psi, \chi \psi, \varphi \chi, \chi^{2}$, we obtain the follow- ing equations:

$$
\begin{aligned}
& Q_{n}=\frac{1}{\Delta_{1}^{2}}\left(\mu^{2} \psi^{2}+\varphi^{2}\right), \\
& Q_{n m}=\frac{2}{\Delta_{1}^{3}}\left(\mu^{2} \Delta \psi^{2}+\Delta \varphi^{2}+\mu^{2} \varphi \psi+\varphi \chi\right), \\
& Q_{m}=\frac{4}{\Delta_{1}^{4}}\left[\begin{array}{l}
\mu^{2}\left(\mu^{2}+\Delta^{2}\right) \psi^{2}+\left(4 \mu^{2}+\Delta^{2}\right) \varphi^{2}+ \\
+2 \mu^{2} \Delta \varphi \psi-2 \mu^{2} \psi \chi+2 \Delta \varphi \chi+\chi^{2}
\end{array}\right] .
\end{aligned}
$$

Since the right-hand sides of equations $\left(4.70^{\prime}\right)$, according to (4.63) and (4.65), are functions of two parameters $\lambda, \mu$, in a three-dimensional space with variables $Q_{n}, Q_{m}, Q_{n m}$ they represent a surface

$$
F\left(Q_{n}, Q_{m}, Q_{n m}\right)=0,
$$

and $\left(4.70^{\prime}\right)$ is the parametric equation of this surface. The relation between the quadratic forms (4.68) obtained in this way is called the final relation between the forces and moments acting in the shells. The final relationship was obtained from the Mizes hypothesis $\sigma_{i}=\sigma_{s}$ and therefore it is a generalization of the Mizes condition. The final relation derived from the equations of the theory of small elastic-plastic deformations will have the same form, according to the theory of flow the Sen-Venan- Mizes.

Existence of a final relation between forces $N$ and the moments $M$ in case of ideal plasticity, i.e. under condition of Mizes and at small elastic deformations, follows and is direct from formulas (4.23') and (4.24') as thus they are uniform zero degree concerning six values $\varepsilon_{1}, \varepsilon_{2}, \varepsilon_{12}, \chi_{1}, \chi_{2}, \chi_{12}$.

The surface (4.70) represents a threedimensional image of the indicated surface of the six-measurement space.

We pass to more in-depth study of a final relation $\left(4.70^{\prime}\right)$. We note three special cases of a final relation. 
A.A. Ilyushin's Final Relation, Alternative Equivalent Relations and Versions of Uts Approximation in Problems of Plastic Deformation of Plates and Shells. Part 1: A.A. Ilyushin's Final Relation

1. The momentless state of stress takes place at

$$
\chi_{1}=\chi_{2}=\chi_{12}=0, \text { with } P_{\varepsilon \chi}=0 \text { (4.68) }
$$

The final relation is obtained from (4.70') if we assume that the deformations of the fibers along the thickness of the shell are the same

$$
e_{i 1}=e_{i 2}=e_{i 0}, \lambda=\mu=1
$$

In formulas (4.63), (4.65), one should take the lower sign and then uncover the uncertainties in formulas $\left(4.70^{\prime}\right)$. Then we find, obviously, the Mizes condition:

$$
Q_{m}=Q_{n m}=0, \quad Q_{n}=1
$$

Or in expanded form:

$$
N_{1}^{2}-N_{1} N_{1}+N_{2}^{2}+3 N_{12}^{2}=N_{s}^{2} .
$$

2. Purely moments the tension takes place in the absence of lengthening of a middle surface. The quadratic form

$$
P_{\varepsilon}=0,
$$

that is why

$$
P_{\varepsilon \chi}=0
$$

As appears from the formula (4.19), intensity of deformations $e_{i}$ is even function $z$ and, according to (4.34), we have

$$
e_{i 1}=e_{i 2}, e_{i 0}=0, \lambda=1, \mu=0 .
$$

In formulas (4.63), (4.65) it is necessary to take the upper sign as from (4.33) it is had $z_{0}=0$, thus we receive

$$
\Delta_{1}=2, \Delta=0, \varphi=0, \mu \psi=0, \chi=2 .
$$

The final relation $(4.70$ ') becomes:

$$
Q_{n}=Q_{n m}=0, Q_{m}=1,
$$

Or in expanded form:

$$
M_{1}^{2}-M_{1} M_{2}+M_{2}^{2}+3 M_{12}^{2}=M_{s}^{2} .
$$

3. The elementary difficult tension of shells at

$$
P_{\chi} \neq 0, P_{\varepsilon} \neq 0
$$

takes place, if the bilinear form $P_{\varepsilon \chi}$ addresses in zero:

$$
P_{\varepsilon \chi}=\chi_{1}\left(\varepsilon_{1}+\frac{1}{2} \varepsilon_{2}\right)+\chi_{2}\left(\varepsilon_{2}+\frac{1}{2} \varepsilon_{1}\right)+\chi_{12} \varepsilon_{12}=0
$$

It can take place in cases

$$
\begin{aligned}
& \text { a) } \chi_{1} \neq 0, \chi_{12}=\chi_{2}=0, \varepsilon_{1}+\frac{1}{2} \varepsilon_{2}=0 \\
& \text { b) } \varepsilon_{1} \neq 0, \varepsilon_{12}=\varepsilon_{2}=0, \chi_{1}+\frac{1}{2} \chi_{2}=0
\end{aligned}
$$

And many other things. From (4.60) it is thus had $e_{i 1}=e_{i 2}>e_{i 0}, \lambda=1, \mu<1$, i.e. dominating bending strain is available. We find:

$$
\begin{aligned}
& \Delta=\varphi=0, \Delta_{1}=\chi=2 \sqrt{1-\mu^{2}}, \\
& \psi=2 \ln \frac{1+\sqrt{1-\mu^{2}}}{\mu},
\end{aligned}
$$

and after simple transformations the final relation becomes: 


$$
\begin{aligned}
& Q_{n}=\frac{\mu^{2}}{1-\mu^{2}} \ln ^{2} \frac{1+\sqrt{1-\mu^{2}}}{\mu}, Q_{n m}=0, \\
& Q_{m}=\left(\frac{\mu^{2}}{1-\mu^{2}} \ln \frac{1+\sqrt{1-\mu^{2}}}{\mu}-\frac{1}{\sqrt{1-\mu^{2}}}\right)^{2} .
\end{aligned}
$$

It gives a line of interception of a surface (4.70) with a plane $Q_{n m}=0$. As $Q_{n}, Q_{m}$ are essentially positive, all surface is disposed between planes

$$
Q_{n}=0 \text { and } Q_{m}=0,
$$

and a line (4.74) between positive directions of axes $Q_{n}, Q_{m}$, i.e. in the first quadrant of a plane

$$
Q_{n m}=0 .
$$

The point

$$
Q_{m}=0, Q_{n}=1
$$

corresponding to a non-propulsive condition of a shell, is received from (4.74) at $\mu=1$, and the point

$$
Q_{n}=0, Q_{m}=1
$$

corresponding purely moment to a condition of a shell, is received at

$$
\mu=0 \text {, as } \mu \ln \mu=0 \text { at } \mu=0 \text {. }
$$

The curve $Q_{n}, Q_{m}$ can be constructed on the points which coordinates are introduced in table 4 [9] (the expanded version of the table it is resulted in 2 parts of the article). On Figure 53 [9] coordinates (it is resulted in 2 parts of the article) the curve (4.74) and a straight line is represented

$$
Q_{n}+Q_{m}=1,
$$

which well enough approximates it. The maxi- mum deviation of a straight line makes about 9 $\%$. The surface (4.70) is symmetric concerning a plane

$$
Q_{n m}=0 .
$$

Thus, it is enough to know about a surface (4.70), only in the first octant of co-ordinate system $Q_{n}, Q_{m}, Q_{n m}$. It is possible to be convinced that on a line $\lambda=1$ in a value plane $\left(Q_{n}, Q_{m}\right) Q_{n}, Q_{m}$ have a maximum. If to use Schwarz's inequality concerning quadratic forms $Q_{n}, Q_{m}, Q_{n m} Q_{n m}^{2} \leq Q_{n} \cdot Q_{m}$, it is possible to conclude that the value $Q_{n m}$ on the module also is limited.

Table 5 [9] (the expanded version of the table is resulted in 2 parts of the article) gives coordinates of some points of a surface on lines $\lambda=$ const , and against each value $\lambda$ are given: in the first line - $Q_{n}$ in the second - $Q_{m}$ and in the third- $Q_{n m}$.

The greatest values $Q_{n m}$ will be, when Schwarz's inequality is transformed into equality

$$
Q_{n m}^{2}=Q_{n} \cdot Q_{m},
$$

and it is possible only when values $n$ and $m$ are proportional:

$$
\frac{n_{1}}{m_{1}}=\frac{n_{2}}{m_{2}}=\frac{n_{12}}{m_{12}}
$$

Let's show that the hyperbolic paraboloid (4.77) is crossed with a surface (4.70) on a line $\mu=0$. From (4.65) at $\mu=0$ it is had:

$$
\begin{aligned}
& \varphi=\lambda-1, \chi=1 \pm \lambda^{2}, \mu \psi=0 \\
& \Delta_{1}=1 \pm \lambda, \Delta=\frac{1-\lambda^{2}}{1 \pm \lambda}
\end{aligned}
$$


A.A. Ilyushin's Final Relation, Alternative Equivalent Relations and Versions of Uts Approximation in Problems of Plastic Deformation of Plates and Shells. Part 1: A.A. Ilyushin's Final Relation

Introducing these values to the equations (4.70), we receive:

$Q_{n}=\frac{\varphi^{2}}{\Delta_{1}^{2}}, Q_{n m}=\frac{2 \varphi}{\Delta_{1}^{3}}(\Delta \varphi+\chi), Q_{m}=\frac{4}{\Delta_{1}^{4}}(\Delta \varphi+\chi)^{2}$

From here in case of a dominating stretching of a shell at the lower sign in (4.77 ") it is had:

$$
Q_{n}=1, Q_{n m}=Q_{m}=0,
$$

I.e. the line $\mu=0$ degenerates in a point.

In case of a dominating bending of a shell it is received:

$Q_{n}=\left(\frac{1-\lambda}{1+\lambda}\right)^{2}, Q_{n m}=-\frac{4 \lambda(1-\lambda)}{(1+\lambda)^{3}}, Q_{m}=\frac{16 \lambda^{2}}{(1+\lambda)^{4}}$,

whence follows (4.77). Besides, from last equations it is found other relation

$$
Q_{m}=\left(1-Q_{n}\right)^{2},
$$

Combining it with (4.77), we find:

$$
\left|Q_{n m}\right|=\left(1-Q_{n}\right) \sqrt{Q_{n}} .
$$

From here we conclude that the line $\mu=0$ determining greatest on the module of value of the bilinear form $Q_{n m}$, represents a line of interception of two parabolic cylinders from which the cylinder (4.79) passes through points:

$$
\begin{aligned}
& Q_{n}=1, Q_{m}=0, Q_{n m}=0, \\
& Q_{n}=0, Q_{m}=1, Q_{n m}=0,
\end{aligned}
$$

Having forming, parallel to co-ordinate $Q_{n m}$, the cylinder (4.80) has forming, parallel to coordinate $Q_{m}$, and passes through the same points. The line $\mu=0$ limiting a piece of a surface (4.70) for dominating bending on which values $Q_{n}, Q_{n m}, Q_{m}$ have mechanical sense, is shown on fig. 54 (it is resulted in 2 parts of the article).

The maximum value of ordinate $Q_{n m}$ on the module will be at

$$
Q_{n}=\frac{1}{3}, Q_{m}=\frac{4}{9}
$$

and

$$
\left|Q_{n m}\right|_{\max }=\frac{2}{3 \sqrt{3}} .
$$

The final relation between forces and the moments in case of a dominating bending matters

$$
\left|Q_{n m}\right|_{\max }=\frac{2}{3 \sqrt{3}} .
$$

can be approximately presented, as pair of the planes passing through a line (4.75) and through points

$$
Q_{n}=\frac{1}{3}, Q_{m}=\frac{4}{9}, Q_{n m}= \pm \frac{2}{3 \sqrt{3}}
$$

They have the equation:

$$
Q_{n}+Q_{m}+\frac{1}{\sqrt{3}}\left|Q_{n m}\right|=1
$$

As six components of deformations and bendings are expressed by means of differential operations on curvilinear coordinates through three components of a displacement vector $u, v, w$ of a middle surface, they should satisfy to the equations of compatibility of deformations.

Generally it is possible to express the compatibility equations through forces $N$ and the moments $M$, but they will contain one more func- 
tion of coordinates $e_{i 1}$. The differential equations of equilibrium and conditions of compatibility of deformations will be insufficiently for definition of forces $N_{1}, N_{2}, N_{12}$, the moments $M_{1}, M_{2}, M_{12}$ and unknown function $e_{i 1}$.

The final relation $\left(4.70^{\prime}\right)$ between forces and the moments will be the missing equation also. In a kind of that this relation not differential and from it follows that forces and the moments and their quadratic forms $Q_{n}, Q_{m}, Q_{n m}$ are limited on value, at any external forces equilibrium of a shell is impossible.

As lift capability of a shell is called limiting value of external forces at which internal forces $N$ and the moments $M$ satisfy to a final relation $\left(4.70^{\prime}\right)$, to the equilibrium equations, conditions of compatibility of deformations and boundary conditions.

In special cases thanks to a final relation the problem about equilibrium becomes statically definable and does not demand conditions of compatibility of deformations. Then the question on lift capability of a shell is decided rather simply.

It more becomes simpler, if forces and the moments can be expressed through external forces only by means of the equilibrium equations that takes place, for example, in the non-propulsive theory of shells, in that case the final relation (4.70') determines lift capability.

Conditions of compatibility of deformations do a problem about definition of lift capability rather difficult and consequently the approximate methods of its solution have great value.

The energy method of the solution consists in the following: are set by the suitable form of the deformed surface of shells and, making expressions of a variation of activity of internal forces and activity of external forces on variations of movings, compare them. Approximate limiting value of external forces can be received, if material hardening to put equal to zero, and deformations beyond all bounds to increase or saving constants yield strength

$$
\sigma_{s}=3 G e_{s},
$$

$G$ to aim to infinity, and $e_{s}$ - to zero.

On Figures 2.1-2.4 the fluidity surface

$$
F\left(Q_{n}, Q_{m}, Q_{n m}\right)=0
$$

in three-dimensional space with variables is presented $Q_{n}, Q_{m}, Q_{n m}$. A black line - section of a surface a plane

$$
Q_{n m}=0,
$$

formulas (4.74), a red line - a line of a maximum $\left.\left|Q_{n m}\right|(4.79)-4.80\right)$.

\subsection{The relationship between internal forces, moments and deformations of the shell on the basis of flow theory for an ideal plastic mate- rial}

We show that the relations (4.26-4.27) remain valid also in the framework of the flow theory. Specific power dissipation of energy per unit volume:

$$
D=\sigma_{x} \dot{\varepsilon}_{x}+\sigma_{y} \dot{\varepsilon}_{y}+\sigma_{z} \dot{\varepsilon}_{z}+\tau_{x y} \dot{\gamma}_{x y}+\tau_{z x} \dot{\gamma}_{z x}+\tau_{z y} \dot{\gamma}_{z y}
$$

The plasticity condition of R. Mizes:

$$
\begin{aligned}
& F=\left(\sigma_{x}-\sigma_{y}\right)^{2}+\left(\sigma_{x}-\sigma_{z}\right)^{2}+\left(\sigma_{y}-\sigma_{z}\right)^{2}+ \\
& +6\left(\tau_{x y}^{2}+\tau_{z x}^{2}+\tau_{z y}^{2}\right)-2 \sigma_{s}^{2}
\end{aligned}
$$

On the basis of the associate law of flow and a postulate of Druker for true fields of speeds of movings power of a dissipation of energy receives the maximum value, speeds of deformations are determined from a condition of a maximum of function 
A.A. Ilyushin's Final Relation, Alternative Equivalent Relations and Versions of Uts Approximation in Problems of Plastic Deformation of Plates and Shells. Part 1: A.A. Ilyushin's Final Relation

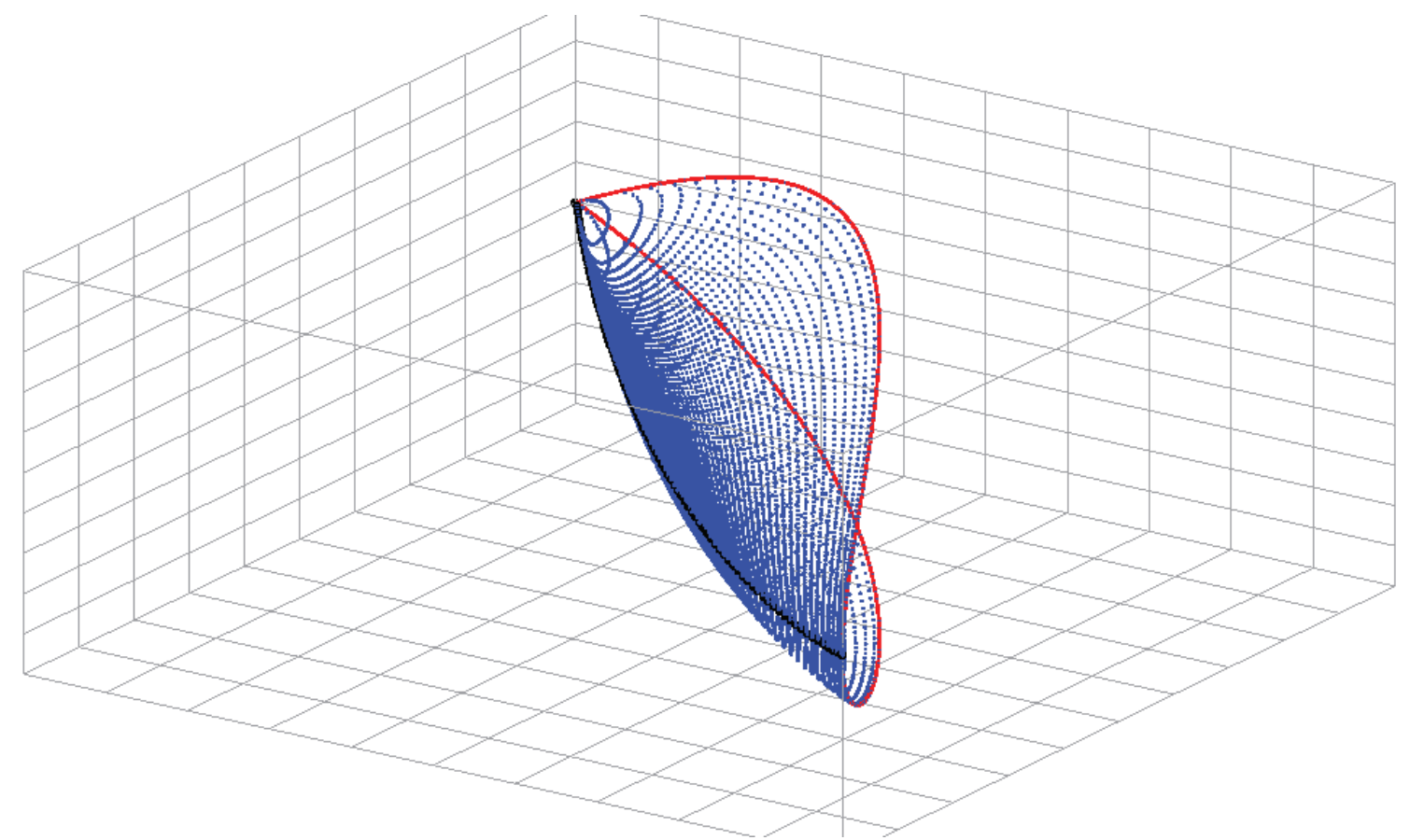

Figure 2.1. A fluidity surface $F\left(Q_{n}, Q_{m}, Q_{n m}\right)=0$ in three-dimensional space with variables $Q_{n}, Q_{m}, Q_{n m}$.

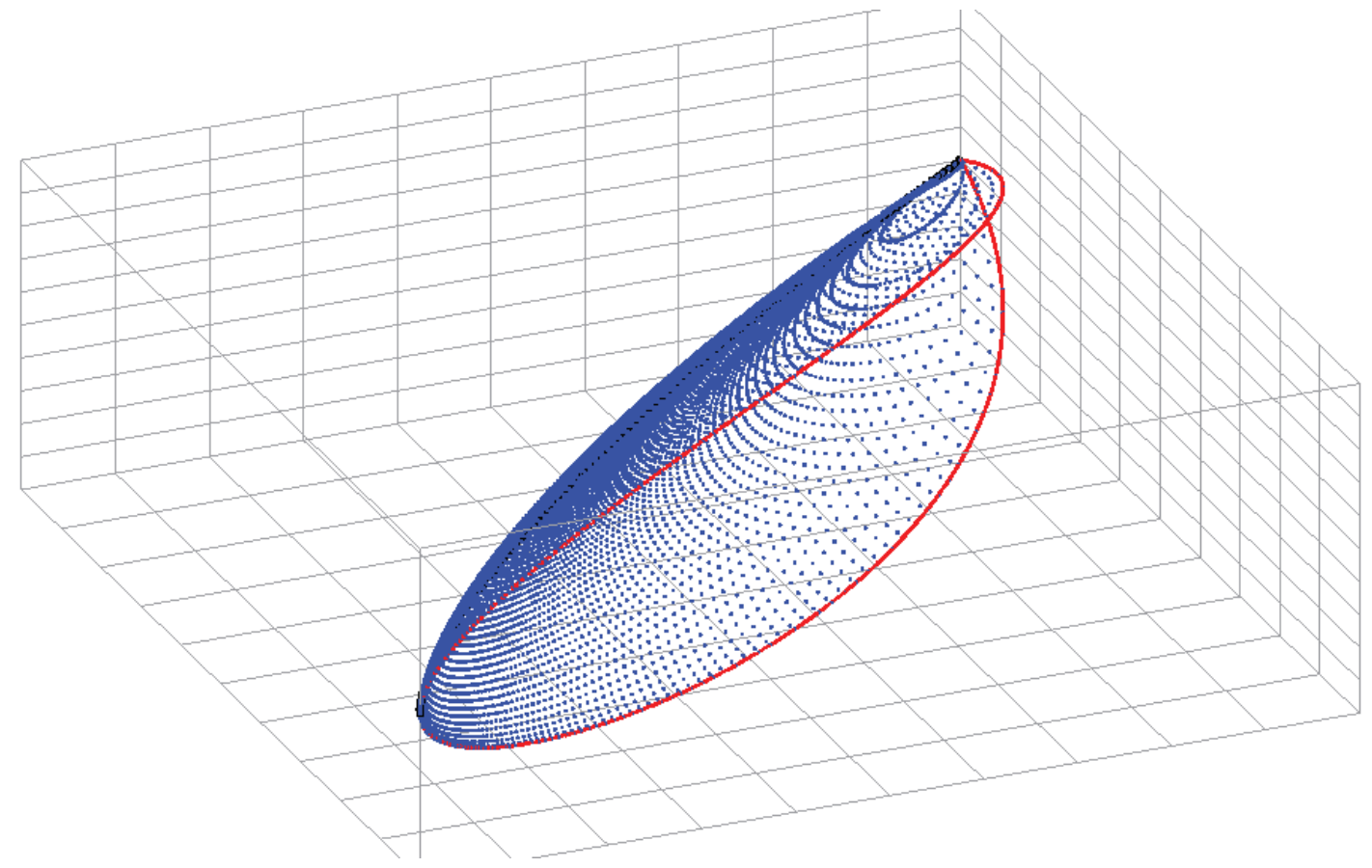

Figure 2.2. A fluidity surface $F\left(Q_{n}, Q_{m}, Q_{n m}\right)=0$ in three-dimensional space with variables $Q_{n}, Q_{m}, Q_{n m}$. 


\begin{tabular}{|l|l|l|l|l|l|l|l|l|l|l|l|l|l|l|l|}
\hline & & & & & & & & & & & & & & & \\
\hline
\end{tabular}

Figure 2.3. A fluidity surface $F\left(Q_{n}, Q_{m}, Q_{n m}\right)=0$ in three-dimensional space with variables $Q_{n}, Q_{m}, Q_{n m}$.

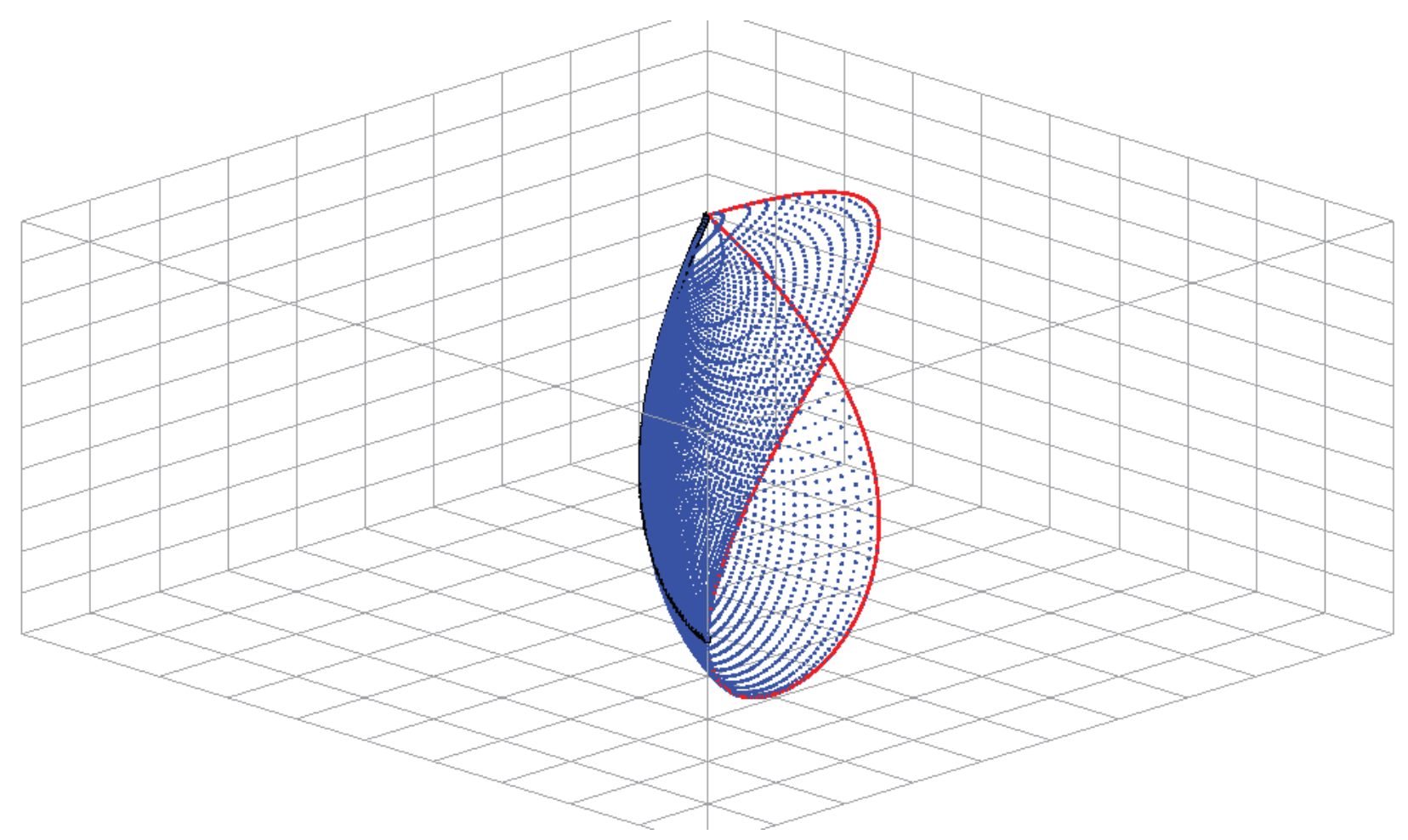

Figure 2.4. A fluidity surface $F\left(Q_{n}, Q_{m}, Q_{n m}\right)=0$ in three-dimensional space with variables $Q_{n}, Q_{m}, Q_{n m}$. 
A.A. Ilyushin's Final Relation, Alternative Equivalent Relations and Versions of Uts Approximation in Problems of Plastic Deformation of Plates and Shells. Part 1: A.A. Ilyushin's Final Relation

$$
\Phi=D-\lambda F
$$

where $D$ and $F$ according to (1.3.1)-(1.3.2):

$$
\begin{aligned}
& \dot{\varepsilon}_{x}=6 \lambda\left(\sigma_{x}-\sigma_{0}\right), \dot{\varepsilon}_{y}=6 \lambda\left(\sigma_{y}-\sigma_{0}\right), \\
& \dot{\varepsilon}_{z}=6 \lambda\left(\sigma_{z}-\sigma_{0}\right), \frac{1}{2} \dot{\gamma}_{x y}=6 \lambda \tau_{x y}, \frac{1}{2} \dot{\gamma}_{x z}=6 \lambda \tau_{x z}, \\
& \frac{1}{2} \dot{\gamma}_{z y}=6 \lambda \tau_{z y}, \sigma_{0}=\frac{\sigma_{x}+\sigma_{y}+\sigma_{z}}{3} .
\end{aligned}
$$

Excluding $\lambda$ by means of (1.3.2), we receive relation of flow of Sen-Venan-Mizes-LeviIshlinsky

$$
\begin{aligned}
& \sigma_{x}-\sigma_{0}=\frac{2 \sigma_{s}}{3 \dot{e}_{i}} \cdot \dot{\varepsilon}_{x}, \sigma_{y}-\sigma_{0}=\frac{2 \sigma_{s}}{3 \dot{e}_{i}} \cdot \dot{\varepsilon}_{y}, \\
& \sigma_{z}-\sigma_{0}=\frac{2 \sigma_{s}}{3 \dot{e}_{i}} \cdot \dot{\varepsilon}_{z}, \tau_{x y}=\frac{2 \sigma_{s}}{3 \dot{e}_{i}} \cdot \frac{1}{2} \dot{\gamma}_{x y}, \\
& \tau_{z x}=\frac{2 \sigma_{s}}{3 \dot{e}_{i}} \cdot \frac{1}{2} \dot{\gamma}_{z x}, \tau_{z y}=\frac{2 \sigma_{s}}{3 \dot{e}_{i}} \cdot \frac{1}{2} \dot{\gamma}_{z y},
\end{aligned}
$$

where intensity of speeds of deformations

$$
\dot{e}_{i}=\frac{\sqrt{2}}{3} \sqrt{\begin{array}{l}
\left(\dot{\varepsilon}_{x}-\dot{\varepsilon}_{y}\right)^{2}+\left(\dot{\varepsilon}_{x}-\dot{\varepsilon}_{z}\right)^{2}+\left(\dot{\varepsilon}_{y}-\dot{\varepsilon}_{z}\right)^{2}+ \\
+\frac{6}{4}\left(\dot{\gamma}_{x y}^{2}+\dot{\gamma}_{z x}^{2}+\dot{\gamma}_{z y}^{2}\right)
\end{array}} .
$$

For a flat tension and problems of a bending of plates and shells it agree hypotheses of Kirhgoffa-Ljava

$$
\sigma_{z}=0, \tau_{z x}=\tau_{z y}=0
$$

and a condition of an incompressibility of a material

$$
\dot{\varepsilon}_{x}+\dot{\varepsilon}_{y}+\dot{\varepsilon}_{z}=0:
$$

$$
\begin{aligned}
& \dot{\varepsilon}_{x}=\dot{\varepsilon}_{1}-\dot{\chi}_{1} z, \dot{\varepsilon}_{y}=\dot{\varepsilon}_{2}-\dot{\chi}_{2} z, \frac{1}{2} \dot{\gamma}_{x y}=\dot{\varepsilon}_{12}-\dot{\chi}_{12} z, \\
& \dot{\varepsilon}_{1}=\left.\dot{\varepsilon}_{x}\right|_{z=0}, \quad \dot{\varepsilon}_{2}=\left.\dot{\varepsilon}_{y}\right|_{z=0}, \dot{\varepsilon}_{12}=\left.\frac{1}{2} \dot{\gamma}_{x y}\right|_{z=0},
\end{aligned}
$$

The equations (1.3.4) and (1.3.5) taking into account (1.3.5) become

$$
\begin{aligned}
& \sigma_{x}=\frac{4 \sigma_{s}}{3 \dot{e}_{i}}\left(\dot{\varepsilon}_{x}+\frac{1}{2} \dot{\varepsilon}_{y}\right)= \\
& =\frac{4 \sigma_{s}}{3 \dot{e}_{i}}\left[\left(\dot{\varepsilon}_{1}+\frac{1}{2} \dot{\varepsilon}_{2}\right)-\left(\dot{\chi}_{1}+\frac{1}{2} \dot{\chi}_{2}\right) z\right], \\
& \sigma_{y}=\sigma_{x}=\frac{4 \sigma_{s}}{3 \dot{e}_{i}}\left(\dot{\varepsilon}_{y}+\frac{1}{2} \dot{\varepsilon}_{x}\right)= \\
& =\frac{4 \sigma_{s}}{3 \dot{e}_{i}}\left[\left(\dot{\varepsilon}_{2}+\frac{1}{2} \dot{\varepsilon}_{1}\right)-\left(\dot{\chi}_{2}+\frac{1}{2} \dot{\chi}_{1}\right) z\right], \\
& \tau_{x y}=\frac{2 \sigma_{s}}{3 \dot{e}_{i}} \cdot \frac{1}{2} \dot{\gamma}_{x y}=\left(\dot{\varepsilon}_{12}-\dot{\chi}_{12} z\right), \\
& \dot{e}_{i}=\frac{2}{\sqrt{3}} \sqrt{\dot{\varepsilon}_{x}^{2}+\dot{\varepsilon}_{x} \dot{\varepsilon}_{y}+\dot{\varepsilon}_{y}^{2}+\frac{1}{4} \dot{\gamma}_{x y}^{2}} .
\end{aligned}
$$

Longitudinal and shearing forces, bending and twisting moments according to (4.21)-(4.22)

$$
\begin{aligned}
& \frac{3}{4} N_{1}=\left(\dot{\varepsilon}_{1}+\frac{1}{2} \dot{\varepsilon}_{2}\right) J_{1}-\left(\dot{\chi}_{1}+\frac{1}{2} \dot{\chi}_{2}\right) J_{2} \\
& \frac{3}{4} N_{2}=\left(\dot{\varepsilon}_{2}+\frac{1}{2} \dot{\varepsilon}_{1}\right) J_{1}-\left(\dot{\chi}_{2}+\frac{1}{2} \dot{\chi}_{1}\right) J_{2},(1 \\
& \frac{3}{2} N_{12}=\dot{\varepsilon}_{12} J_{1}-\dot{\chi}_{12} J_{2} \\
& \frac{3}{4} M_{1}=\left(\dot{\varepsilon}_{1}+\frac{1}{2} \dot{\varepsilon}_{2}\right) J_{2}-\left(\dot{\chi}_{1}+\frac{1}{2} \dot{\chi}_{2}\right) J_{3} \\
& \frac{3}{4} M_{2}=\left(\dot{\varepsilon}_{2}+\frac{1}{2} \dot{\varepsilon}_{1}\right) J_{2}-\left(\dot{\chi}_{2}+\frac{1}{2} \dot{\chi}_{1}\right) J_{3},(1.3 . \\
& \frac{3}{2} M_{12}=\dot{\varepsilon}_{12} J_{2}-\dot{\chi}_{12} J_{3},
\end{aligned}
$$


where integrals $J_{1}, J_{2}, J_{3}$ :

$$
J_{1}=\int_{-\frac{h}{2}}^{\frac{h}{2}} \frac{\sigma_{s}}{\dot{e}_{i}} d z, J_{2}=\int_{-\frac{h}{2}}^{\frac{h}{2}} \frac{\sigma_{s}}{\dot{e}_{i}} z d z, J_{3}=\int_{-\frac{h}{2}}^{\frac{h}{2}} \frac{\sigma_{s}}{\dot{e}_{i}} z^{2} d z,
$$

and intensity of speeds of deformations:

$$
\begin{aligned}
& \dot{e}_{i}=\frac{2}{\sqrt{3}} \sqrt{\dot{P}_{\varepsilon}-2 z \dot{P}_{\varepsilon \chi}+z^{2} \dot{P}_{\chi}}, \\
& \dot{P}_{\varepsilon}=\dot{\varepsilon}_{1}^{2}+\dot{\varepsilon}_{1} \dot{\varepsilon}_{2}+\dot{\varepsilon}_{2}^{2}+\dot{\varepsilon}_{12}^{2}, \dot{P}_{\chi}=\dot{\chi}_{1}^{2}+\dot{\chi}_{1} \dot{\chi}_{2}+\dot{\chi}_{2}^{2}+\dot{\chi}_{12}^{2}, \\
& \dot{P}_{\varepsilon \chi}=\dot{\varepsilon}_{1} \dot{\chi}_{1}+\dot{\varepsilon}_{2} \dot{\chi}_{2}+\frac{1}{2} \dot{\varepsilon}_{1} \dot{\chi}_{2}+\frac{1}{2} \dot{\varepsilon}_{2} \dot{\chi}_{1}+\dot{\varepsilon}_{11} \dot{\chi}_{12} .
\end{aligned}
$$

Thus the final relation remains fair and within the limits of the flow theory if in all formulas of sections 1.1-1.2 to replace deformations $\varepsilon_{1}, \varepsilon_{2}, \varepsilon_{12}$ and changes of curvature of a median surface $\chi_{1}, \chi_{2}, \chi_{12}$ with speeds of deformations $\dot{\varepsilon}_{1}, \dot{\varepsilon}_{2}, \dot{\varepsilon}_{12}$ and speed of change of curvature of a median surface $\dot{\chi}_{1}, \dot{\chi}_{2}, \dot{\chi}_{12}$. For the hardening account in formulas it is necessary to consider (1.3.11) yield strength as function of intensity of deformations and intensity of speeds of deformations $\sigma_{s}=\sigma_{s}\left(e_{i}, \dot{e}_{i}\right)$.

\section{CONCLUSIONS}

The geometrical image of an exact surface of fluidity in space of the generalised pressure which A.A. Ilyushin in the works and in references is absent that allows to execute its approximation for the solution of practical problems is received. It is shown that a final relation remain fair and within the limits of the theory of flow for ideally plastic material.

\section{REFERENCES}

1. Kijko I.A., Brovko G.L., Vasin R.A. (Eds.) K 100-letiju so dnja rozhdenija A.A. Il'ju-shina (20.01.1911-31.05.1998) // Uprugost' i neuprugost' [To the 100 anniversary from the date of A.A. Ilyushin's birth (20.01.1911-31.05.1998) Elasticity and inelasticity]. // Materials of the International scientific symposium on problems of mechanics of the deformable bodies, devoted to the 100 anniversary from the date of A.A. Ilyushin's birth. Moscow, Publishing house of the Moscow university, 2011, pp. 9-12 (in Russian).

2. Aleksej Antonovich Il'jushin: k 100-letiju so dnja rozhdenija [Alexey Antonovich Ilyushin: to the 100 anniversary from the date of a birth]. // Bulletin of the Tyumen state university. Physical and mathematical modelling. Oil, gas, power, 2010, No. 6, pp. 198-203 (in Russian).

3. K 100-letiju so dnja rozhdenija A.A. Il'jushina [To the 100 anniversary from the date of A.A. Ilyushin's birth]. // News of the Russian Academy of Sciences. Mechanics of a firm body, 2011, No. 1, pp. 3-4 (in Russian).

4. K 100-letiju so dnja rozhdenija Alekseja Antonovicha Il'jushina (20.01.191131.05.1998) [To the 100 anniversary from the date of Alexey Antonovicha Ilyushin's birth (20.01.1911-31.05.1998)]. // The Bulletin of the Moscow university. Series 1: Mathematics. Mechanics, 2011, No. 1, pp. 77-79 (in Russian).

5. Ilyushina E.A. Nadjozhnost' $v$ nauke i zhizni (k 95-letiju so dnja rozhdenija A.A. Il'jushina) [Reliability in a science and life (to the 95 anniversary from the date of A.A.Ilyushin's birth)]. // News of the Russian Academy of Sciences. Mechanics of a firm body, 2005, No. 6, pp. 3 (in Russian).

6. Brovko G.L., Bykov D.L., Vasin R.A., Georgievsky D.V., Kijko I.A., Molodsov I.N., Pobedrja B.E. Nauchnoe nasledie 
A.A. Ilyushin's Final Relation, Alternative Equivalent Relations and Versions of Uts Approximation in Problems of Plastic Deformation of Plates and Shells. Part 1: A.A. Ilyushin's Final Relation

A.A. Il'jushina i razvitie ego idej v mehanike [A.A.Ilyushin's scientific heritage and development of its ideas in the mechanic]. // News of the Russian Academy of Sciences. Mechanics of a firm body, 2011, No. 1, pp. 5-18 (in Russian).

7. Kadymov V.A., Nutsubidze D.V. Tvorcheskoe nasledie professora A.A. Il'jushina i ego vklad v pobedu v Velikoj Otechestvennoj vojne [The Creative heritage of professor A.A.Ilyushin and its contribution to a victory in the Great Patriotic War]. // Human. Society. Inclusion, 2015, No. 2(22), pp. 10-13 (in Russian).

8. Bondar V.S., Vasin R.A., Kijko I.A. Shkola-seminar "A.A. Il'jushin - vydajushhijsja mehanik sovremennosti" v MGTU "MAMI" [School-seminar "A.A.Ilyushin the outstanding mechanic of the present" in MGTU "MAMI"]. // Problems of engineering and automation, 2011, No. 3, pp. 136139 (in Russian).

9. Ilyushin A.A. Plastichnost'. Chast' pervaja. Uprugo-plasticheskie deformacii [Plasticity. Part 1. Elasto-plastic deformations]. Moscow, Gostehizdat, 1948, 376 pages (in Russian).

10. Ilyushin A.A., Shemjakina E.I., Kijko I.A., Vasin R.A. Plastichnost'. Chast' 1. Uprugo-plasticheskie deformacii [Plasticity. Part 1. Elasto-plastic deformations]. Moscow, Publishing house Logos, Moscow, 2004, 388 pages (in Russian).

11. Ilyushin A.A. Trudy. T. 1 (1935-1945) [Works. P.1 (1935-1945)] / Composers: E.A. Ilyushin, N.R. Korotkina. Moscow, Publishing house of the physical and mathematical literature, 2003, 352 pages (in Russian).

12. Ilyushin A.A. Trudy (1946-1966) Chast' 2 Plastichnost' [Works (1946-1966). P.2. Plasticity] / Composers E.A. Ilyushin, M.R. Korotkina. Moscowm Publishing house of the physical and mathematical literature, 2004, 480 pages (in Russian).

13. Ilyushin A.A. Konechnoe sootnoshenie mezhdu silami i momentami i ih svjazi s deformacijami $\mathrm{v}$ teorii obolochek [Final a ratio between forces and the moments and their communications with deformations in the theory of shells]. // Applied mathematics and mechanics, 1945, No. 1, pp. 101-110 (in Russian).

14. Ilyushin A.A. Priblizhennaja teorija uprugo-plasticheskih deformacij osesimmetrichnyh obolochek [Approach the theory of elasto-plastic deformations of axisymmetrical shells]. // Applied mathematics and mechanics, 1944, No. 8, pp. 15-24 (in Russian).

15. Olshak V., Savchuk A. Neuprugoe povedenie obolochek [Not Elastic behaviour of shells]. Moscow, Mir, 1969, 144 pages (in Russian).

16. Olshak V., Mruz Z., Pezhina P. Sovremennoe sostojanie teorii plastichnosti [The current state of the theory of plasticity]. Moscow, Mir, 1964, 243 pages (in Russian).

17. Rozhdestvensky V.V. K voprosu o predel'nyh sostojanijah sechenij tonkih obolochek [To a question on limiting conditions of sections of the thin shells]. // Researches concerning the building mechanics and the plasticity theory, Moscow, 1956, pp. 223-233 (in Russian).

18. Shapiro G.S. O poverhnostjah tekuchesti dlja ideal'no plasticheskih obolochek [About surfaces of fluidity for ideally plastic shells]. // Continuum Problems, to the 70 anniversary of academician N.I. Mushelishvili. Moscow, Publishing house AN of the USSR, 1961, pp. 504-507 (in Russian).

19. Hodge P.G. Yield conditions for rotationally symmetric shells under axisymmetric loading. // J. Appl. Mech., I960, No. 2, 27, pp. 323-331.

20. Hodge P.G. The Mises yield conditions for rotationally symmetric shells. // Quart. Appl. Math., 1961, Vol. 18, pp. 305-311.

21. Hodge P.G. A comparison of yield conditions in the theory of plastic shells. // Prob- 
lems in continuum mechanics, SIAM, Philadelphia, 1961, pp. 165-177.

22. Hodge P.G. The theory of rotationally symmetric plastic shells. // Non-classical shell problems. Amsterdam, North-Holland Publishing Company, 1964, pp. 621-648.

23. Drucker D.C., Hopkins H.G. Combined Concentrated and Distributed Load on Ideally - Plastic Circular Plates. // Proc. 2nd U.S. Nat. Cong. App. Mech., 1954, pp. 517520 (in Russian).

24. Drucker D.C. Plastic design methods - advantages and limitations. // Trans. Soc. Nav., Eng., 1957, Vol. 65, pp. 172-196.

25. Drucker D.C., Shield R.T. Limit analysis of symmetrically loaded thin shells of revolution. // Appl. Mech., 1959, Vol. 26, pp. 61-68.

26. Onat E.T. The plastic collapse of cylindrical shells under axially symmetrical loading. // Quart. Appl. Math., 1955, Vol. 13, pp. 68-72.

27. Onat E.T., Prager W. Limit analysis of shells of revolution. // Proc. Ned. Akad. Wetensch., 1954, Vol. 57, Ser. B, pp. 534548.

28. Onat E.T. Plastic shells, Non-classical shell problems. // Amsterdam, NorthHolland Publishing Company, 1967, pp. 649-659.

29. Jones N. Plasticity Methods in Protection and Safety of Industrial Plant and Structural Systems Against Extreme Dynamic Loading. // Defence Science Journal, 2008, Vol. 58, No. 2, pp. 181-193.

30. Jones N. Structural impact. United Kingdom, Cambridge University Press, 2003, 591 pages.

31. Nemirovsky JU.V., Romanova T.P. Dinamicheskoe soprotivlenie ploskih plasticheskih pregrad [Dynamic resistance of flat plastic barriers]. Novosibirsk, Publishing house Geo, 2009, 312 pages (in Russian).

32. Erhov M.I. Teorija ideal'no plasticheskih tel i konstrukcij [The theory of ideally plas- tic bodies and designs]. Moscow, The Science, 1978, 352 pages (in Russian).

33. Erhov M.I. Konechnoe sootnoshenie mezhdu silami i momentami pri plasticheskoj deformacii obolochek [Between forces and the moments at plastic deformation of shells]. // The building mechanics and calculation of facilities, 1959, No. 3, pp. 38-41 (in Russian).

34. Rozenbljum V.I. Ob uslovii plastichnosti dlja tonkostennyh obolochek [About a condition of plasticity for thin-walled shells]. // Applied mathematics and mechanics, 1960, Vol. 24, pp. 364-366 (in Russian).

35. Rozenbljum V.I. O polnoj sisteme uravnenij plasticheskogo ravnovesija tonkostennyh obolochek [About full system of the equations of plastic equilibrium of thin-walled shells]. // The engineering Magazine. Mechanics of a solid body, 1966, No. 3, pp. 483-492.

36. Rozenbljum V.I. O raschete nesushhej sposobnosti ideal'no plasticheskih osesimmetrichnyh obolochek [About calculation of lift capability of ideally plastic axisymmetrical shells]. // Questions of the theory of elasticity and plasticity. Leningrad, Publishing house of the Leningrad state university, 1965, pp. 67-75 (in Russian).

37. Rozenbljum V.I. O raschete nesushhej sposobnosti ideal'no plasticheskih osesimmetrichnyh obolochek [About calculation of lift capability of ideally plastic axisymmetrical shells]. // Researches on elasticity and plasticity. Leningrad, Publishing house of the Leningrad state university, 1965, pp. 207-218 (in Rissian).

38. Rozenbljum V.I. Priblizhennaja teorija ravnovesija plasticheskih obolochek [The approximate theory of equilibrium of plastic shells]. // Applied mathematics and mechanics, 1954, Volume 18, 3, pp. 289-302 (in Russian).

39. Rabotnov JU.N. Priblizhennaja tehnicheskaja teorija uprugo-plasticheskih ob- 
A.A. Ilyushin's Final Relation, Alternative Equivalent Relations and Versions of Uts Approximation in Problems of Plastic Deformation of Plates and Shells. Part 1: A.A. Ilyushin's Final Relation

olochek [Approach the technical theory $\mathrm{t}$ is elastic the plastic shells]. // Applied mathematics and mechanics, 1951, Volume 15, Issue 2, pp. 167-174 (in Russian).

40. Birger I.A., Panovko J.G. (Eds.) Prochnost', ustojchivost', kolebanija. Spravochnik $\mathrm{v}$ treh tomah. Tom 2 [Strength, stability, oscillations. A directory in three volumes. Volume 2]. Moscow, Engineering, 1968. 463 pages (in Russian).

41. Korolev V.I. Uprugo-plasticheskie deformacii obolochek [Elasto-plastic deformations of shells]. Moscow, Engineering, 1971, 304 pages.

42. Ogibalov P.M. Voprosy dinamiki i ustojchivosti obolochek [Questions of dynamics and stability of shells]. Moscow, Publishing house of the Moscow university, 1963, 420 pages.

43. Dvajt G.B. Tablicy integralov i drugie matematicheskie formuly [Tables of integrals and other mathematical formulas]. Moscow, Science, 1966, 228 pages (in Russian).

44. Vygodsky M.Ja. Spravochnik po vysshej matematike [The Directory on higher mathematics]. Moscow, Science, 1977, 872 pages (in Russian).

45. Starov A.V. Polnaja sistema uravnenij dinamicheskogo udarnogo nagruzhenija zhestkoplasticheskih pologih obolochek vrashhenija $\mathrm{s}$ uchetom bol'shih progibov [Full system of the equations of dynamic impact loading rigidly plastic shallow shells of rotation taking into account large deflections]. // Building mechanics of engineering designs and facilities, 2011, No. 4, pp. 2631 (in Russian).

\section{СПИСОК ЛИТЕРАТУРЫ}

1. Кийко И.А., Бровко Г.Л., Васин Р.А. (ред.) К 100-летию со дня рождения А.А. Ильюшина (20.01.1911-31.05.1998) // Упругость и неупругость / Материаль Международного научного симпозиума по проблемам механики деформируемых тел, посвященного 100-летию со дня рождения А.А. Ильюшина. - М: Издательство Московского университета, 2011, c. 9-12.

2. Алексей Антонович Ильюшин: к 100летию со дня рождения. // Вестник Тюменского государственного университета. Физико-математическое моделирование. Нефть, газ, энергетика, 2010, №6, c. 198-203.

3. К 100-летию со дня рождения А.А. Ильюшина. // Известия Российской академии наук. Механика твердого тела, 2011, №1, c. 3-4.

4. К 100-летию со дня рождения Алексея Антоновича Ильюшина (20.01.191131.05.1998). // Вестник Московского университета. Серия 1: Математика. Механика, 2011, №1, с. 77-79.

5. Ильюшина Е.А. Надёжность в науке и жизни (к 95-летию со дня рождения А.А. Ильюшина). Известия Российской академии наук. Механика твердого тела, 2005, №6, c. 3.

6. Бровко Г.Л., Быков Д.Л., Васин Р.А., Георгиевский Д.В., Кийко И.А., Молодцов И.Н., Победря Б.Е. Научное наследие А.А. Ильюшина и развитие его идей в механике. // Известия Российской академии наук. Механика твердого тела, 2011, №1, с. 5-18.

7. Кадымов В.А., Нуцубидзе Д.В. Творческое наследие профессора А.А. Ильюшина и его вклад в победу в Великой Отечественной войне. // Человек. Общество. Инклюзия, 2015, №2(22), с. 10-13.

8. Бондарь В.С., Васин Р.А., Кийко И.А. Школа-семинар «А.А. Ильюшин - выдающийся механик современности» В МГТУ «МАМИ». // Проблемы машиностроения и автоматизачии, 2011, №3, с. 136-139.

9. Ильюшин А.А. Пластичность. Часть первая. Упруго-пластические деформации. - М: Гостехиздат, 1948. - 376 с. 
10. Ильюшин А.А. Пластичность. Часть первая. Упруго-пластические деформации / Науч. предисл. Е.И. Шемякина, И.А. Кийко, Р.А. Васина. Репр. воспр. текста изд. 1948 г. - М: Логос, 2004. $388 \mathrm{c.}$.

11. Ильюшин А.А. Труды. Том 1 (19351945). / Составители: Е.А. Ильюшина, Н.Р. Короткина. - М.: Физматлит, 2003. $-352 \mathrm{c}$.

12. Ильюшин А.А. Труды (1946-1966). Том 2. Пластичность. / Составители Е.А. Ильюшина, М.Р. Короткина. - М.: Физматлит , 2004. - 480 с.

13. Ильюшин А.А. Конечное соотношение между силами и моментами и их связи с деформациями в теории оболочек. // ПММ, 1945, №1, с. 101-110.

14. Ильюшин А.А. Приближенная теория упруго-пластических деформаций осесимметричных оболочек. // ПММ, 1944, №8, с. 15-24.

15. Ольшак В., Савчук А. Неупругое поведение оболочек. - М: Мир, 1969. - 144 с.

16. Ольшак В., Мруз 3., Пежина П. Современное состояние теории пластичности. - М: Мир, 1964. - 243 с.

17. Рождественский В.В. К вопросу о предельных состояниях сечений тонких оболочек. // Исследования по вопросам строительной механики и теории пластичности. - М: ЦНИПС, 1956, с. 223233.

18. Шапиро Г.С. О поверхностях текучести для идеально пластических оболочек. // Проблемы сплошной среды, к 70-летию академика Н. И. Мусхелишвили. - М: Изд-во АН СССР, 1961, с. 504-507.

19. Hodge P.G. Yield conditions for rotationally symmetric shells under axisymmetric loading. // J. Appl. Mech., I960, No. 2, 27, pp. 323-331.

20. Hodge P.G. The Mises yield conditions for rotationally symmetric shells. // Quart. Appl. Math., 1961, Vol. 18, pp. 305-311.

21. Hodge P.G. A comparison of yield condi- tions in the theory of plastic shells. // Problems in continuum mechanics, SIAM, Philadelphia, 1961, pp. 165-177.

22. Hodge P.G. The theory of rotationally symmetric plastic shells. // Non-classical shell problems. Amsterdam, North-Holland Publishing Company, 1964, pp. 621-648.

23. Drucker D.C., Hopkins H.G. Combined Concentrated and Distributed Load on Ideally - Plastic Circular Plates. // Proc. 2nd U.S. Nat. Cong. App. Mech., 1954, pp. 517520 (in Russian).

24. Drucker D.C. Plastic design methods - advantages and limitations. // Trans. Soc. Nav., Eng., 1957, Vol. 65, pp. 172-196.

25. Drucker D.C., Shield R.T. Limit analysis of symmetrically loaded thin shells of revolution. // Appl. Mech., 1959, Vol. 26, pp. 61-68.

26. Onat E.T. The plastic collapse of cylindrical shells under axially symmetrical loading. // Quart. Appl. Math., 1955, Vol. 13, pp. 68-72.

27. Onat E.T., Prager W. Limit analysis of shells of revolution. // Proc. Ned. Akad. Wetensch., 1954, Vol. 57, Ser. B, pp. 534548.

28. Onat E.T. Plastic shells, Non-classical shell problems. // Amsterdam, NorthHolland Publishing Company, 1967, pp. 649-659.

29. Jones N. Plasticity Methods in Protection and Safety of Industrial Plant and Structural Systems Against Extreme Dynamic Loading. // Defence Science Journal, 2008, Vol. 58, No. 2, pp. 181-193.

30. Jones N. Structural impact. United Kingdom, Cambridge University Press, 2003, 591 pages.

31. Немировский Ю.В., Романова Т.П. Динамическое сопротивление плоских пластических преград. - Новосибирск: Издательство Гео, 2009. - 312 с.

32. Ерхов М.И. Теория идеально пластических тел и конструкций. - М: Наука, 1978. -352 c. 
A.A. Ilyushin's Final Relation, Alternative Equivalent Relations and Versions of Uts Approximation in Problems of Plastic Deformation of Plates and Shells. Part 1: A.A. Ilyushin's Final Relation

33. Ерхов М.И. Конечное соотношение между силами и моментами при пластической деформации оболочек. // Строительная механика и расчет сооружений, 1959, №3, c. 38-41.

34. Розенблюм В.И. Об условии пластичности для тонкостенных оболочек. // ПММ, 1960, том 24, с. 364-366.

35. Розенблюм В.И. О полной системе уравнений пластического равновесия тонкостенных оболочек. // Инж. журнал. МТT, 1966, №3, с. 483-492.

36. Розенблюм В.И. О расчете несущей способности идеально пластических осесимметричных оболочек. // Bonросы теории упругости и пластичности. - Л.: ЛГУ, 1965, с. 67-75.

1. Розенблюм В.И. О расчете несущей способности идеально пластических осесимметричных оболочек. // Исследования по упругости и пластичности. - М.: - Л.: ЛГУ, 1965, с. 207-218.

37. Розенблюм В.И. Приближенная теория равновесия пластических оболочек / В.И. Розенблюм // ПММ, 1954, Том 18, Выпуск 3, с. 289-302.

38. Работнов Ю.Н. Приближенная техническая теория упругопластических оболочек. // ПММ, 1951, Том 15, Выпуск 2, с. 167-174.

39. Биргер И.А., Пановко Я.Г. (ред.) Прочность, устойчивость, колебания. Справочник в трех томах. Том 2. - М: Машиностроение, 1968. - 463 с.

40. Королев В.И. Упруго-пластические деформации оболочек. - М: Машиностроение, 1971. - 304 c.

41. Огибалов П.М. Вопросы динамики и устойчивости оболочек. - М: Издательство Московского университета, 1963. $420 \mathrm{c}$.

42. Двайт Г.Б. Таблицы интегралов и другие математические формулы. - М.: Наука, 1966. - 228 с.

43. Выгодский М.Я. Справочник по высшей математике. - М.: Наука, 1977. -
$872 \mathrm{c}$.

44. Старов А.В. Полная система уравнений динамического ударного нагружения жесткопластических пологих оболочек вращения с учетом больших прогибов / А.В. Старов. // Строительная механика инженерных конструкций и сооружений, 2011, №4, с. 26-31.

Starov Aleksandr Vasil'evich, Associate Professor, Doctor of Engineering Science, Associate Professor of Structural Mechanics Department, Volgograd State Technical University. 1, Akademicheskaya St., Volgograd, 400074, Russian Federation; e-mail: starov1954@mail.ru.

Kalashnikov Sergey Yur'evich, Advisor of the Russian Academy of Architecture and Construction Sciences (RAACS), Professor, Doctor of Engineering Science, Professor, Academician of the International Higher Education Academy of Sciences, Vice-Rector, Volgograd State Technical University. 1, Akademicheskaya St., Volgograd, 400074, Russian Federation;

E-mail: kalashnikov@vstu.ru.

Старов Александр Васильевич, доцент, доктор технических наук, доцент кафедры строительной механики, Волгоградский государственный технический университет (ВолгГТУ); 400074, Россия, г. Волгоград, ул. Академическая, 1; e-mail: starov1954@mail.ru.

Калашников Сергей Юрьевич, советник Российской академии архитектуры и строительных наук (РАACH), профессор, доктор технических наук, проректор, Волгоградский государственный технический университет (ВолгГТУ); 400074, Россия, г. Волгоград, ул. Академическая, 1; e-mail: kalashnikov@vstu.ru. 